\title{
A Bibliometric History of the Journal of Psychology Between 1936 and 2015
}

\author{
Ana Tur-Porcar, Alicia Mas-Tur, José M. Merigó, Norat Roig-Tierno \& John \\ Watt
}

To cite this article: Ana Tur-Porcar, Alicia Mas-Tur, José M. Merigó, Norat Roig-Tierno \& John Watt (2018) A Bibliometric History of the Journal of Psychology Between 1936 and 2015, The Journal of Psychology, 152:4, 199-225, DOI: 10.1080/00223980.2018.1440516

To link to this article: https://doi.org/10.1080/00223980.2018.1440516

\section{Published online: 03 Apr 2018.}

Submit your article to this journal ¿

Llll Article views: 28

Q View related articles $\square$

View Crossmark data 5 


\title{
A Bibliometric History of the Journal of Psychology Between 1936 and 2015
}

\author{
Ana Tur-Porcar ${ }^{a}$, Alicia Mas-Tur ${ }^{a}$, José M. Merigó ${ }^{b}$, Norat Roig-Tierno ${ }^{c, d}$, and John Watt ${ }^{e}$

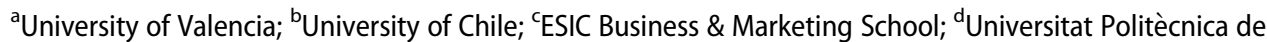 \\ Valencia; ${ }^{\mathrm{T}}$ Texas A\&M University
}

\begin{abstract}
The Journal of Psychology: Interdisciplinary and Applied is a leading international journal in psychology dating back to 1935 . This study examines its publications since its creation utilizing a bibliometric analysis. The primary objective is to provide a complete overview of the key factors affecting the journal. This analysis includes such key issues as the publication and citation structure of the journal, its most cited articles, and the leading authors, institutions, and countries referenced in the journal. The work uses the Scopus database to classify the bibliographic material. Additionally, the analysis provides a graphical mapping of the bibliographic data by using visualization of similarities viewer software. This software uses several bibliometric techniques including co-citation, bibliographic coupling and cooccurrence of keywords. The Journal of Psychology is strongly connected to most of the current leading journals in psychology, and currently has a 5-year impact factor of 1.77 (Thomson Reuters, 2015 Journal Citation Reports).
\end{abstract}

\section{ARTICLE HISTORY}

Received 30 January 2018

Accepted 4 February 2018

\section{KEYWORDS}

Bibliometrics; journal

analysis; psychology; Scopus

The Journal of Psychology: Interdisciplinary and Applied is a double-blind, peer-review international journal published by Taylor \& Francis. It publishes empirical and theoretical articles in such applied areas of psychology as behavioral psychology, cognitive psychology, clinical psychology, educational psychology, consumer psychology and environmental psychology. In addition, the journal seeks to publish interdisciplinary contributions that integrate other disciplines with psychology such as law, economics, politics and religion.

The journal was founded in 1935 in response to the accelerated growth of psychological research. At this point in time, psychology was in full expansion at an academic, institutional, and empirical level.

The publication of the journal has continued uninterrupted until the present day and was the first to publish one or two issues per year (1935 and 1936). From 1937 and until 1964, it went on to publish two volumes per year, two issues for each one. Between 1966 and 1984, the journal published six two-issue volumes a year. In 1985, the editors restructured the internal layout of the journal, organizing it into six annual numbers published in a volume

CONTACT Alicia Mas-Tur $\otimes$ alicia.mas@uv.es E Departamento de Dirección de Empresas, Universitat de Valéncia, Avenida Tarongers, Valencia, S/N 46022, Spain.

Color versions of one or more of the figures in the article can be found online at www.tandfonline.com/VJRL. 
and that continued until the year 2015, when the number of published issues increased to eight per year.

Currently, the executive editors of the journal include: Ron Downey (Kansas State University), Ami Rokach (York University; The Center for Academic Studies, Israel) and John Watt (Texas A \& M University). The Journal of Psychology publishes eight issues per year, and is one of the top journals in the field with an impact factor of 1.25 according to 2016 Thomson Reuters, 2015 Journal Citation Reports ${ }^{\circledR}$, and a 5-year impact factor of 1.765 (Reuters, 2015).

The primary purpose of this study is to examine The Journal of Psychology's published articles according to the leading articles, authors, institutions, and countries using a bibliometric approach. This method provides a qualitative and quantitative analysis of the journal's contribution to the scientific community through a close analysis of the articles published by the journal. This analysis was conducted using data from the Scopus database. Minimal discrepancies/faults, however, may appear given that Scopus sometimes is not consistent in how it provides the data. This research paper aims at providing an extensive analysis of the development of the publication structure and the citations that derive from the journal based on the most productive authors, institutions, and countries. Understanding the factors that guide the journal can be interesting for the scientific community as well as the journal's target audience.

A bibliometric approach has been applied to other disciplines and in a multitude of different areas. Namely, economy (Coupé, 2003), innovation (Fagerberg, Fosaas, \& Sapprasert, 2012), entrepreneurship (Landström, Harirchi, \& Aström, 2012), health economics (Wagstaff \& Culyer, 2012) and management (Podsakoff, MacKenzie, Podsakoff, \& Bachrach, 2008). Additionally, various studies developed a bibliometric analysis of specific journals, including the Journal of Business Research (Merigó, Mas-Tur, Roig-Tierno, \& Ribeiro-Soriano, 2015), the Journal of Business and Industrial Marketing (Valenzuela et al., 2017), International Journal of Intelligent Systems (Merigó, Blanco-Mesa, Gil-Lafuente, \& Yager, 2017) and European Journal of Operational Research (Laengle et al., 2017).

\section{Method}

A common way to measure research activity is through metrics associated with publications in peer-reviewed journals (Carleton et al., 2012). These metrics include a recount of articles and citations, as well as factor-impact assessed through the h-index (Hirsch, 2005). This index takes into account the productivity and impact of a set of publications (Krampen, Becker, Wahner, \& Montada, 2007). The impact of research and productivity correlate positively (Feist, 1997).

This study focuses on publications by The Journal of Psychology over a nearly 80 year period (i.e., 1936 to 2015). The study of bibliometrics allows for the use of different techniques to obtain the data of interest; however, the techniques that are more commonly used are those focusing on the number of studies and the total number of times cited. In addition to these two factors, this study also presents the number of citations per article and the number of studies per person in the section regarding productivity by country. Additionally, the results are in some cases presented according to different thresholds. For instance, the results corresponding to an author indicate the number of studies, the total times the studies were cited, and then the number of articles cited more than 50 times, more than 25 times, and more than 10 times. 
Other indicators included are the $h$-index and the impact factor of the journal per year as per the existing records. These structured results allow for a more informed assessment of the rankings, as will be shown in each particular section of the results.

The h-index is designed to integrate a person's publications and citations in a single measurement (Harzing, 2010; Hirsch, 2005). For example, a researcher with a $20 h$-index has 20 publications that have received at least 20 citations. However, this index does not take into account other publications by the same author particularly if he/she has received a small number of citations. Other indices are the (i) G-index, which draws on the h-index but only focuses on the articles that have a high number of citations (Egghe, 2006; Harzing, 2010), (ii) the hl-index, which takes into account co-authorship, and (iii) the annual index-hl, which provides a researchers' average influence throughout his or her career (Harzing, Alakangas, \& Adams, 2014). Although there is currently some controversy about the best measure to describe the professional profile (Podsakoff et al., 2008), the main assumption is that the number of publications reflects the researcher's productivity and the number of citations refers to the impact of the author in his/her community.

In order to gain a better image of The Journal of Psychology's contribution towards the scientific community, this study includes the most significant indicators that offer a comprehensive overview of published production. The tables that appear in this paper display sets of analyses from different perspectives, including productivity influence within the scientific community, institutions, and countries. In addition, the study includes the quotations/article ratio to measure the influence of the article and the indicator of the number of items that have a certain level of influence (Merigó, Gil-Lafuente, \& Yager, 2015).

The information analyzed in the paper is available on the Scopus database and was retrieved between August and October 2016. The results offer an up-to-date bibliographic overview of The Journal of Psychology during the time period indicated.

\section{Results}

This section presents the results of the bibliometric analysis of studies published between 1936 and 2015 by The Journal of Psychology utilizing the Scopus database. The results include articles, notes, and reviews, as is the general practice in this method. The total number of documents amounted to 7392, with a total number of citations of 42846 and an $h$ index of 59. The $h$-index indicates the $h$ number of articles that have been cited $h$ times. In this case, it means that The Journal of Psychology has 59 articles that have been cited at least 59 times. In addition, each article has been cited on average 9.06 times.

\section{Publication Evolution and Citation Structure of The Journal of Psychology}

The results for the first year of publication of The Journal of Psychology are to be expected. In 1936 only 14 items were published; however, the total citations of these studies are surprisingly high (104), which indicates a good acceptance and moderate impact in relative terms. The progress of the journal in terms of citations and number of publications is rather irregular. During the first decades, the number of publications increased, except for selected years. Table 1 shows the citation structure for all years (1936-2015), while Figures 1 and 2 present a graph with the publication evolution for different periods. 
Table 1. Citation Structure of The Journal of Psychology.

\begin{tabular}{|c|c|c|c|c|c|c|c|c|c|c|c|}
\hline Year & $\mathrm{TP}$ & $\mathrm{TC}$ & $\mathrm{H}$ & $\geq 75$ & $\geq 50$ & $\geq 25$ & $\geq 10$ & $\geq 5$ & $\geq 1$ & $\begin{array}{l}\text { Impact } \\
\text { Factor }\end{array}$ & $\begin{array}{c}5 \mathrm{Y} \text { Impac } \\
\text { Factor }\end{array}$ \\
\hline 1936 & 14 & 104 & 5 & 0 & 0 & 1 & 3 & 5 & 11 & - & - \\
\hline 1937 & 69 & 273 & 8 & 0 & 2 & 2 & 6 & 13 & 39 & - & - \\
\hline 1938 & 66 & 194 & 7 & 0 & 0 & 2 & 5 & 7 & 32 & - & - \\
\hline 1939 & 56 & 290 & 7 & 0 & 2 & 3 & 7 & 11 & 32 & - & - \\
\hline 1940 & 66 & 485 & 8 & 2 & 3 & 3 & 7 & 13 & 31 & - & - \\
\hline 1941 & 41 & 171 & 7 & 1 & 1 & 1 & 3 & 10 & 22 & - & - \\
\hline 1942 & 12 & 64 & 2 & 0 & 1 & 1 & 1 & 1 & 6 & - & - \\
\hline 1943 & 36 & 31 & 2 & 0 & 0 & 0 & 0 & 1 & 17 & - & - \\
\hline 1944 & 40 & 84 & 5 & 0 & 0 & 0 & 2 & 7 & 17 & - & - \\
\hline 1945 & 54 & 590 & 6 & 1 & 1 & 1 & 3 & 10 & 25 & - & - \\
\hline 1946 & 71 & 1250 & 6 & 3 & 3 & 4 & 6 & 9 & 18 & - & - \\
\hline 1947 & 76 & 141 & 7 & 0 & 0 & 2 & 4 & 9 & 23 & - & - \\
\hline 1948 & 93 & 838 & 10 & 1 & 2 & 3 & 10 & 13 & 43 & - & - \\
\hline 1949 & 71 & 232 & 8 & 0 & 0 & 2 & 7 & 12 & 39 & - & - \\
\hline 1950 & 35 & 218 & 7 & 0 & 0 & 4 & 7 & 7 & 21 & - & - \\
\hline 1951 & 34 & 99 & 6 & 0 & 0 & 1 & 3 & 7 & 19 & - & - \\
\hline 1952 & 36 & 154 & 7 & 0 & 1 & 1 & 5 & 8 & 16 & - & - \\
\hline 1953 & 71 & 275 & 9 & 0 & 1 & 2 & 9 & 15 & 36 & - & - \\
\hline 1954 & 77 & 357 & 8 & 2 & 2 & 3 & 8 & 16 & 41 & - & - \\
\hline 1955 & 63 & 280 & 9 & 0 & 1 & 2 & 8 & 16 & 39 & - & - \\
\hline 1956 & 45 & 212 & 6 & 0 & 1 & 3 & 5 & 10 & 24 & - & - \\
\hline 1957 & 59 & 247 & 10 & 0 & 0 & 1 & 11 & 15 & 31 & - & - \\
\hline 1958 & 63 & 161 & 7 & 0 & 0 & 1 & 5 & 11 & 31 & - & - \\
\hline 1959 & 77 & 316 & 9 & 0 & 1 & 3 & 8 & 19 & 41 & - & - \\
\hline 1962 & 86 & 403 & 10 & 0 & 1 & 4 & 13 & 23 & 51 & - & - \\
\hline 1963 & 124 & 374 & 10 & 1 & 1 & 1 & 10 & 25 & 71 & - & - \\
\hline 1964 & 176 & 296 & 8 & 0 & 0 & 2 & 6 & 20 & 72 & - & - \\
\hline 1965 & 216 & 359 & 8 & 1 & 1 & 2 & 5 & 18 & 87 & - & - \\
\hline 1966 & 171 & 398 & 9 & 0 & 0 & 3 & 9 & 24 & 79 & - & - \\
\hline 1967 & 227 & 518 & 10 & 1 & 1 & 2 & 10 & 24 & 95 & - & - \\
\hline 1968 & 208 & 438 & 9 & 0 & 0 & 3 & 9 & 24 & 110 & - & - \\
\hline 1969 & 151 & 580 & 10 & 1 & 3 & 6 & 11 & 26 & 83 & - & - \\
\hline 1970 & 160 & 585 & 13 & 1 & 1 & 5 & 18 & 27 & 89 & - & - \\
\hline 1971 & 169 & 325 & 9 & 0 & 0 & 0 & 7 & 19 & 96 & - & - \\
\hline 1972 & 200 & 485 & 10 & 0 & 1 & 2 & 11 & 29 & 105 & - & - \\
\hline 1973 & 132 & 367 & 8 & 1 & 1 & 1 & 6 & 15 & 81 & - & - \\
\hline 1974 & 142 & 398 & 10 & 1 & 1 & 3 & 11 & 15 & 73 & - & - \\
\hline 1975 & 98 & 431 & 11 & 0 & 0 & 5 & 13 & 23 & 55 & - & - \\
\hline 1976 & 154 & 548 & 12 & 0 & 0 & 2 & 15 & 35 & 100 & - & - \\
\hline 1977 & 164 & 602 & 12 & 0 & 0 & 3 & 17 & 41 & 111 & - & - \\
\hline 1978 & 135 & 531 & 12 & 1 & 2 & 2 & 13 & 35 & 90 & - & - \\
\hline 1979 & 130 & 566 & 12 & 0 & 1 & 2 & 18 & 38 & 87 & - & - \\
\hline 1980 & 309 & 1783 & 20 & 2 & 6 & 13 & 56 & 106 & 213 & - & - \\
\hline 1981 & 141 & 739 & 13 & 0 & 1 & 7 & 18 & 45 & 101 & - & - \\
\hline 1982 & 129 & 799 & 13 & 1 & 1 & 5 & 30 & 50 & 98 & - & - \\
\hline 1983 & 154 & 799 & 13 & 1 & 1 & 4 & 26 & 49 & 109 & - & - \\
\hline 1984 & 144 & 842 & 15 & 1 & 2 & 7 & 26 & 47 & 100 & - & - \\
\hline 1985 & 91 & 492 & 11 & 0 & 2 & 4 & 12 & 30 & 67 & - & - \\
\hline 1986 & 75 & 604 & 13 & 1 & 2 & 6 & 18 & 28 & 58 & - & - \\
\hline 1987 & 85 & 546 & 14 & 0 & 1 & 3 & 21 & 35 & 66 & - & - \\
\hline 1988 & 74 & 815 & 14 & 2 & 6 & 9 & 21 & 35 & 55 & - & - \\
\hline 1989 & 77 & 706 & 16 & 0 & 0 & 10 & 23 & 38 & 58 & - & - \\
\hline 1990 & 86 & 686 & 14 & 1 & 2 & 7 & 25 & 38 & 61 & - & - \\
\hline 1991 & 89 & 524 & 12 & 0 & 1 & 3 & 18 & 34 & 65 & - & - \\
\hline 1992 & 89 & 720 & 15 & 0 & 2 & 5 & 24 & 44 & 63 & - & - \\
\hline 1993 & 94 & 854 & 18 & 1 & 3 & 9 & 28 & 41 & 77 & - & - \\
\hline 1994 & 110 & 1250 & 18 & 1 & 3 & 11 & 29 & 42 & 71 & - & - \\
\hline 1995 & 83 & 816 & 15 & 1 & 4 & 8 & 22 & 43 & 65 & - & - \\
\hline 1996 & 93 & 652 & 14 & 0 & 0 & 4 & 23 & 51 & 84 & - & - \\
\hline
\end{tabular}


Table 1. (Continued)

\begin{tabular}{|c|c|c|c|c|c|c|c|c|c|c|c|}
\hline Year & TP & TC & $\mathrm{H}$ & $\geq 75$ & $\geq 50$ & $\geq 25$ & $\geq 10$ & $\geq 5$ & $\geq 1$ & $\begin{array}{l}\text { Impact } \\
\text { Factor }\end{array}$ & $\begin{array}{l}5 Y \text { Impact } \\
\text { Factor }\end{array}$ \\
\hline 1997 & 100 & 846 & 15 & 0 & 2 & 8 & 29 & 54 & 92 & 0.250 & - \\
\hline 1998 & 93 & 1288 & 19 & 3 & 6 & 12 & 39 & 59 & 86 & 0.162 & - \\
\hline 1999 & 82 & 1161 & 20 & 1 & 3 & 11 & 43 & 61 & 77 & 0.287 & - \\
\hline 2000 & 109 & 975 & 15 & 0 & 5 & 9 & 28 & 54 & 98 & 0.341 & - \\
\hline 2001 & 97 & 1242 & 17 & 1 & 2 & 9 & 32 & 58 & 89 & 0.421 & - \\
\hline 2002 & 106 & 1099 & 18 & 1 & 2 & 8 & 35 & 67 & 93 & 0.220 & - \\
\hline 2003 & 58 & 807 & 16 & 1 & 3 & 8 & 29 & 38 & 52 & 0.361 & - \\
\hline 2004 & 37 & 726 & 17 & 0 & 1 & 14 & 24 & 27 & 35 & 0.371 & - \\
\hline 2005 & 36 & 824 & 13 & 1 & 3 & 7 & 19 & 31 & 36 & 0.525 & - \\
\hline 2006 & 41 & 537 & 13 & 0 & 0 & 7 & 16 & 32 & 40 & 0.561 & - \\
\hline 2007 & 62 & 862 & 17 & 1 & 2 & 8 & 29 & 47 & 62 & 0.513 & 0.886 \\
\hline 2008 & 72 & 764 & 17 & 0 & 1 & 5 & 32 & 54 & 69 & 0.575 & 1.031 \\
\hline 2009 & 84 & 1537 & 21 & 5 & 7 & 17 & 35 & 50 & 75 & 0.649 & 1.105 \\
\hline 2010 & 49 & 507 & 13 & 0 & 2 & 3 & 20 & 33 & 48 & 0.848 & 1.159 \\
\hline 2011 & 29 & 194 & 9 & 0 & 0 & 0 & 8 & 16 & 28 & 0.781 & 1.077 \\
\hline 2012 & 52 & 372 & 11 & 0 & 0 & 3 & 15 & 25 & 44 & 0.804 & 1.253 \\
\hline 2013 & 32 & 97 & 6 & 0 & 0 & 0 & 3 & 7 & 22 & 0.952 & 1.384 \\
\hline 2014 & 36 & 59 & 4 & 0 & 0 & 0 & 0 & 2 & 24 & 1.757 & 1.925 \\
\hline 2015 & 89 & 50 & 3 & 0 & 0 & 0 & 0 & 1 & 27 & 1.250 & 1.765 \\
\hline \multirow[t]{3}{*}{2016} & 37 & 2 & 1 & 0 & 0 & 0 & 0 & 0 & 2 & 1.642 & 2.182 \\
\hline & 7392 & 42846 & - & 44 & 112 & 338 & 1191 & 2178 & 4699 & & \\
\hline & $100 \%$ & & & $0.60 \%$ & $1.52 \%$ & $4.57 \%$ & $16.11 \%$ & $29.46 \%$ & $63.57 \%$ & & \\
\hline
\end{tabular}

Abbreviations: TP $=$ Total publications; $\mathrm{TC}=$ Total citations; $\mathrm{H}=\mathrm{h}$-index; $\geq 75, \geq 50, \geq 25, \geq 10, \geq 5, \geq 1=$ Number of documents with equal or more than $75,50,25,10,5$ and 1 citation.

Following the publication of 14 articles in the journal's founding year (i.e., 1936), that number increased to 69 articles the following year. This approximate number is maintained until 1942, where there was a significant decrease to 12 during World War II. The most remarkable period of the series is during 1964-1984. During the period 1980-2009 the number of studies cited more than 25 times increases and is reasonably consistent (between 6 and 12 studies most years). This result is a quality indicator, but also represents the expansion of research thanks to the surge of the Internet because, even though its more user-friendly version appeared in the nineties, the texts published during the previous decades could be easily added a posteriori to a database.

The published articles received approximately 43,000 citations. A more detailed analysis reveals that 44 articles received more than 75 citations, 112 articles received between 50 and

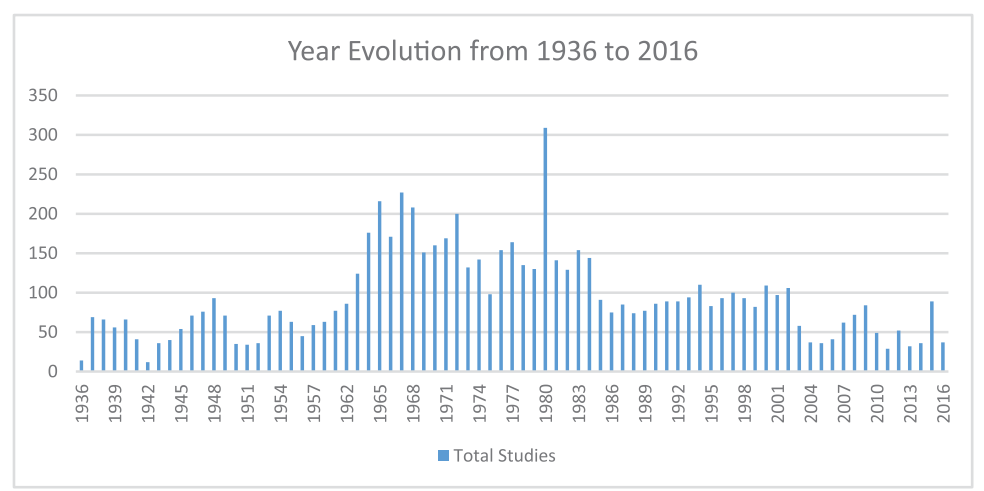

Figure 1. Publication evolution 1936-2016. 


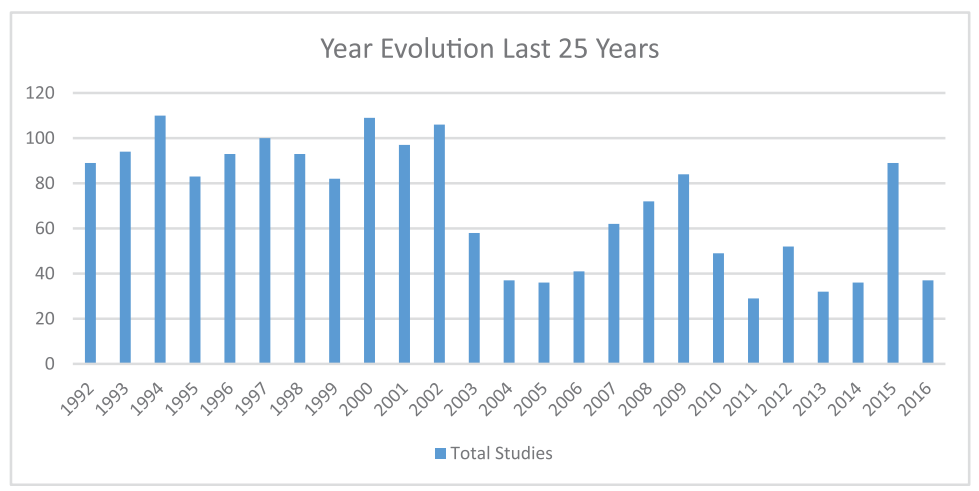

Figure 2. Publication evolution 1992-2016.

74 citations, and 338 articles received between 25 and 49 citations. To some extent, the pace of progress concerning the number of citations throughout this period has been rather steady. Even so, discernible peaks were produced in the years 1946, 1994-1998, 1999, 2001, and 2002, with figures exceeding 1100 and 1200 citations. Similarly, the most outstanding peaks were produced in 1980 and 2009, when the number of citations reached an impressive 1783 and 1537, respectively (Table 1 ).

Table 1 also reflects the impact factor (IF) of the journal according to the measure of Web of Science (WoS) platform. The IF reflects the number of citations in a year of the documents published in years $\mathrm{x}-1, \mathrm{x}-2$. The IF index has been criticized because it is easy to manipulate (Bonilla, Merigó, \& Torres-Abad, 2015). For this reason, the WoS uses IF for 5 years as it seems more robust against possible manipulations. The Journal of Psychology has been included uninterruptedly in the WoS since 1997. The first year it had an impact factor of 0.250 , which fell slightly after the second year, and since 1998 this IF has seen an increase, reaching up to 1.250 in 2015 (latest year available in the WoS). The journal is located in Quartile 2 of the category Psychology-Multidisciplinary (Rank 56/129).

Focusing on the period 1980-2016, the annual number of research published has decreased. It's not clear if this decrease is shared by other psychology journals. Despite the influence in quality production, the advent of the Internet may have also produced the decrease in publications: since authors have access to a greater variety of published works, they may find that some of the ideas have already been developed and published elsewhere. Although in the last years the number of publications has been reasonable, the number of citations is still understandably low. This result is normal given that publications are recent and the typical time lag that occurs between publication and subsequent citation by others. It is important to note that the full results for 2016 are incomplete given that this study was performed before the end of that year.

\section{Most Cited Papers}

Table 2 presents the most cited papers published in The Journal of Psychology according to Scopus. The Journal of Psychology has had and still continues to have an important influence on the research field of psychology. This success is represented in the following chart in the times articles published in this journal have been cited. 


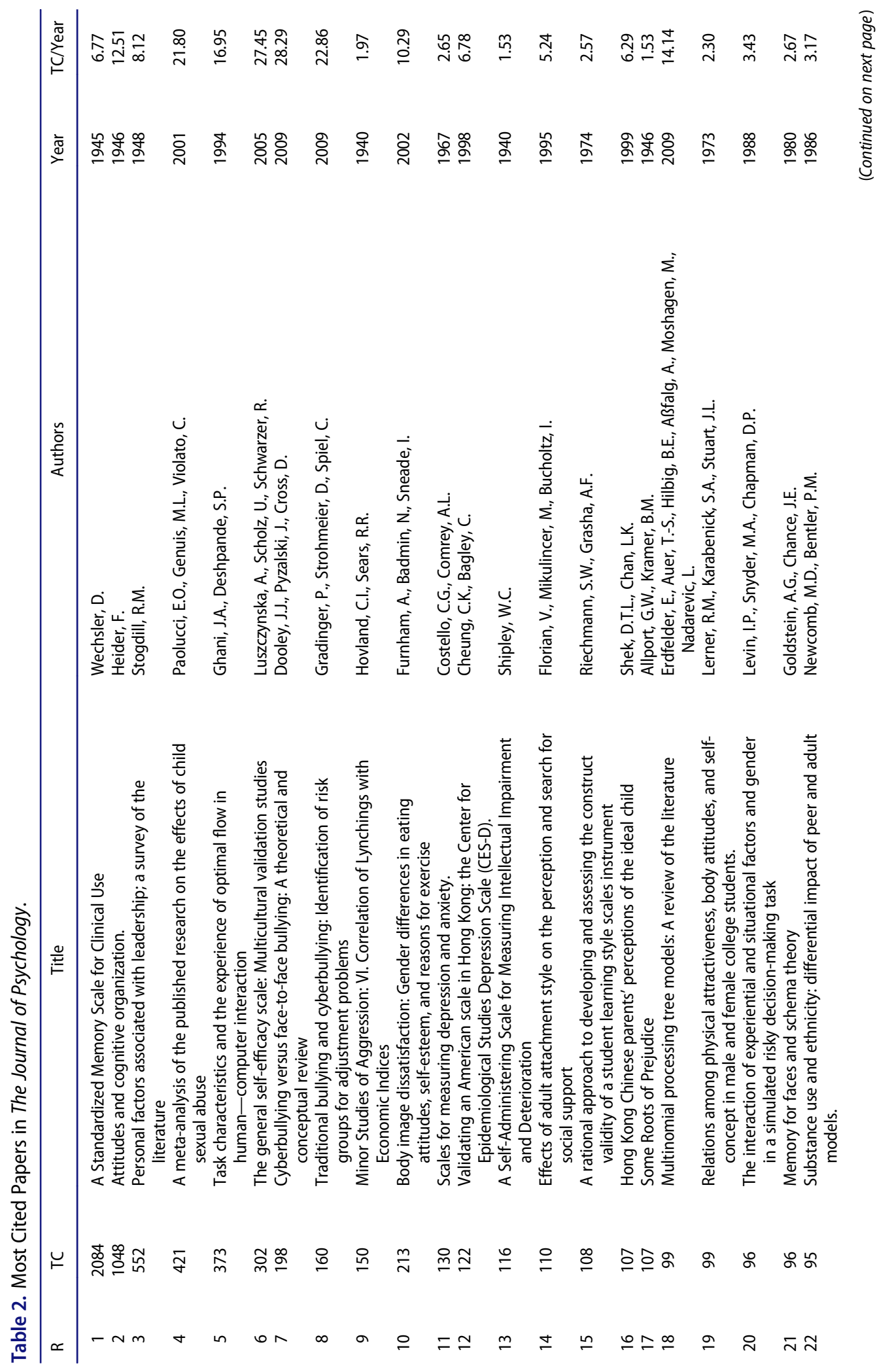




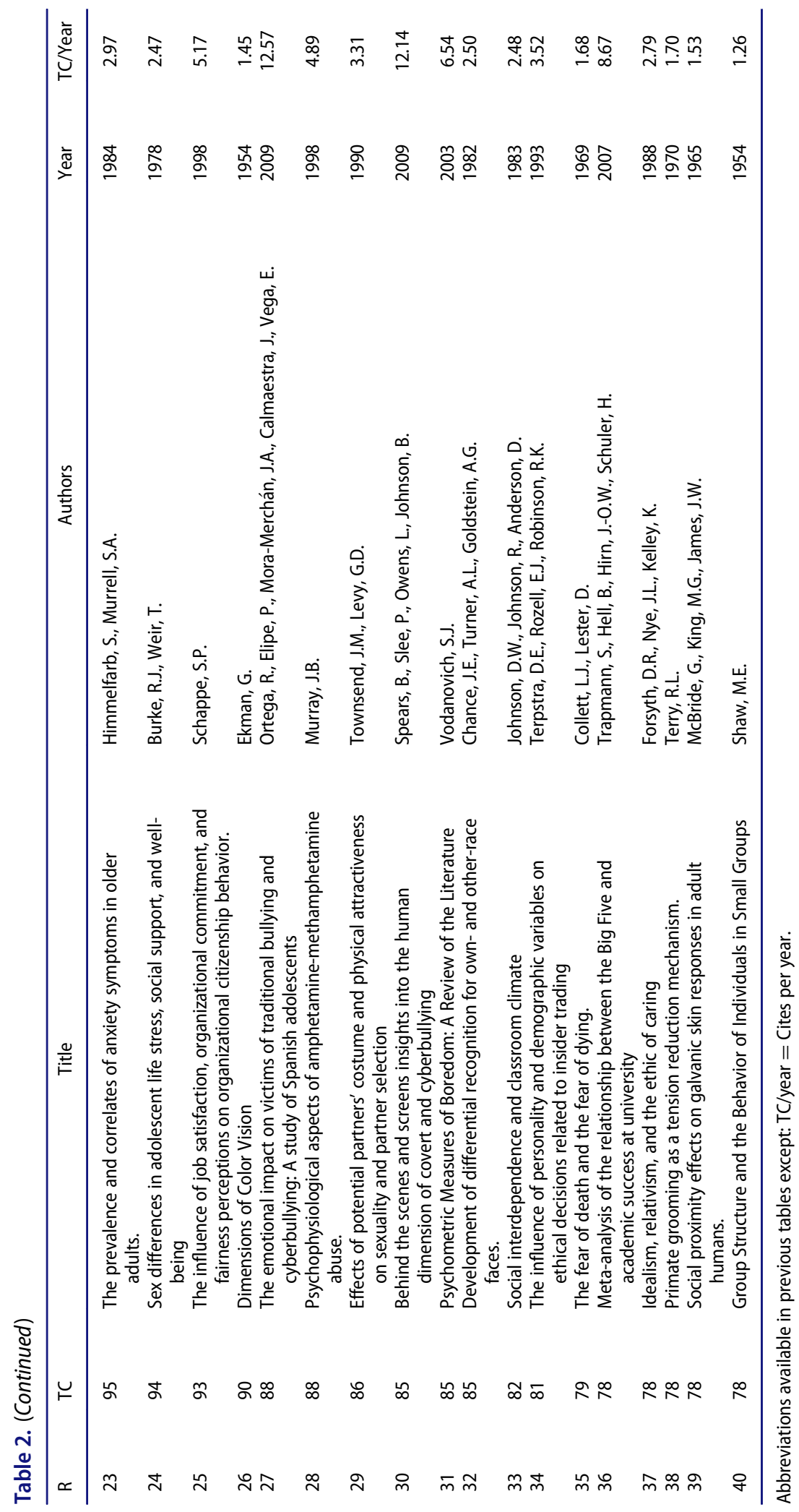


Only the sum of the two most cited articles, by Heider (1946) and Stogdill (1948), exceeds 1400 citations. Below, the five most cited articles are described in detail. The first refers to "Attitudes and cognitive organization," by Heider (1946), and deals with the relationship between attitudes toward an event and the person or entity that caused a particular event. The central focus of Heider's research is on the nature of interpersonal relations and the theory of attribution, articulated into two categories, internal attributions (personal) and external (situational) powers (Heider, 1958) receiving 12.51 citations per year. The second most cited article is by Stogdill (1948) and is titled "Personal factors associated with leadership: a survey of the literature." The popularity of the article may owe in this case to the fact that the author provides a review of the literature on a particular topic, which can still today be consulted by other scholars to build their own literature review. Were it not for this article, it would probably be impossible in some cases to access texts dating as far back as the first decades of the twentieth century. This article receives an average of 16.95 citations per year.

David Wechsler occupies the third position in Table 2 with his paper on the evaluation of the report entitled "A standardized memory scale for clinical use." Wechsler devoted his research at the Bellevue Psychiatric Hospital in New York to the operation of memory and intelligence, devising ways of measuring the intellectual ratios and ratios of memory. This article describes how to obtain a MQ (memory quotients), focusing on spatial and temporal orientation, mind control, immediate memory of logical material, forward and reverse, digit visual reproduction and learning and recalling/retaining, using a list of 10 associated partners. This article has received a total of 481 citations and an average of 6.77 citations. D. Wechsler is the author of the Wechsler Adult Intelligence Scale (WAIS), Wechsler Intelligence Scale for Children (WISC) and the Wechsler Preschool and Primary Scale of Intelligence (WPPSI), which has worldwide recognition.

Paolucci, Genuis, and Violato's (2001) article "A meta-analysis of the published research on the effects of child sexual abuse," which again stresses the popularity of articles dealing with the analysis of existing research, holds the fifth position. Interestingly, the top three articles date from the nineteen forties and nine articles in this list date from the same decade. Four of the ten most cited articles are from the 2000's, which is significant because despite the short time lapsed after their publication, they have obtained a considerable amount of recognition from other scholars. A remarkable case is that of the article by Dooley, Pyzalski, and Cross (2009), which receives 28.29 citations per year and appears in the seventh position of the chart. This qualitative and conceptual study focused on similarities and differences between cyberbullying and bullying. The discussion on this issue continues due to the increase in cases of harassment and cyberbullying suffered by children and adolescents.

\section{Most Influential Countries}

Perhaps unsurprisingly, authors from the USA rank first with 4170 studies and 19,920 total citations received. Articles published in the USA are the most cited, with 18 articles receiving more than 75 citations, 56 items receiving between 50 and 74 citations, and 159 articles receiving between 25 and 49 citations (Table 3).

On another note, the first four countries on the list -USA, Canada, UK, and Australiaare Anglophone countries, which is to be expected to some extent given that the language the journal publishes in is English and other countries may diversify their publication in journals in other languages. 
Table 3. The Most Productive Countries in The Journal of Psychology (1936-2016).

\begin{tabular}{|c|c|c|c|c|c|c|c|c|c|c|c|c|c|}
\hline $\mathrm{R}$ & Country & TS & TC & $\mathrm{H}$ & $\mathrm{TC} / \mathrm{TS}$ & $\geq 75$ & $\geq 50$ & $\geq 25$ & $\geq 10$ & $\geq 5$ & Pop & TS/Pop & TC/Pop \\
\hline 1 & USA & 4170 & 19920 & 51 & 4,78 & 18 & 56 & 159 & 559 & 1031 & 313.232.044 & 13,31 & 63,60 \\
\hline 2 & Canada & 253 & 2074 & 23 & 8,20 & 2 & 10 & 23 & 61 & 96 & 35.099 .836 & 7,21 & 59,09 \\
\hline 3 & UK & 137 & 1457 & 19 & 10,64 & 2 & 4 & 13 & 41 & 58 & 64.088 .222 & 2,14 & 22,73 \\
\hline 4 & Australia & 106 & 943 & 15 & 8,90 & 2 & 2 & 6 & 26 & 48 & 21.766 .711 & 4,87 & 43,32 \\
\hline 5 & Germany & 84 & 1507 & 20 & 17,94 & 3 & 7 & 15 & 35 & 53 & 81.471 .834 & 1,03 & 18,50 \\
\hline 6 & Israel & 79 & 595 & 12 & 7,53 & 2 & 2 & 5 & 21 & 28 & 7.473 .052 & 10,57 & 79,62 \\
\hline 7 & Netherlands & 38 & 376 & 11 & 9,89 & 0 & 1 & 5 & 14 & 16 & 16.847 .007 & 2,26 & 22,32 \\
\hline 8 & Turkey & 38 & 257 & 9 & 6,76 & 0 & 0 & 3 & 8 & 18 & 78.785 .548 & 0,48 & 3,26 \\
\hline 9 & South Africa & 36 & 117 & 7 & 3,25 & 0 & 0 & 0 & 1 & 13 & 49.004 .031 & 0,73 & 2,39 \\
\hline 10 & China & 49 & 615 & 13 & 12,55 & 1 & 3 & 8 & 18 & 26 & 1.336 .718 .015 & 0,04 & 0,46 \\
\hline 11 & Italy & 24 & 176 & 7 & 7,33 & 0 & 1 & 2 & 5 & 9 & 61.016 .804 & 0,39 & 2,88 \\
\hline 12 & Sweden & 23 & 200 & 8 & 8,70 & 0 & 1 & 2 & 6 & 9 & 9.088 .728 & 2,53 & 22,01 \\
\hline 13 & Nigeria & 22 & 36 & 3 & 1,64 & 0 & 0 & 0 & 0 & 2 & 155.215 .573 & 0,14 & 0,23 \\
\hline 14 & Taiwan & 21 & 186 & 9 & 8,86 & 0 & 0 & 1 & 7 & 10 & 23.071 .779 & 0,91 & 8,06 \\
\hline 15 & Belgium & 17 & 182 & 8 & 10,71 & 0 & 0 & 2 & 8 & 9 & 10.431 .477 & 1,63 & 17,45 \\
\hline 16 & New Zealand & 17 & 56 & 5 & 3,29 & 0 & 0 & 0 & 0 & 5 & 4.290 .347 & 3,96 & 13,05 \\
\hline 17 & Japan & 15 & 122 & 5 & 8,13 & 0 & 1 & 1 & 3 & 5 & 126.475 .664 & 0,12 & 0,96 \\
\hline 18 & Switzerland & 14 & 163 & 8 & 11,64 & 0 & 0 & 2 & 7 & 9 & 7.639 .961 & 1,83 & 21,34 \\
\hline 19 & India & 14 & 70 & 6 & 5,00 & 0 & 0 & 0 & 3 & 6 & 1.189 .172 .906 & 0,01 & 0,06 \\
\hline 20 & Spain & 13 & 209 & 6 & 16,08 & 1 & 2 & 2 & 6 & 8 & 46.754 .784 & 0,28 & 4,47 \\
\hline 21 & France & 13 & 76 & 5 & 5,85 & 0 & 0 & 0 & 5 & 6 & 65.312 .249 & 0,20 & 1,16 \\
\hline 22 & Austria & 12 & 264 & 7 & 22,00 & 1 & 1 & 1 & 5 & 9 & 8.217 .280 & 1,46 & 32,13 \\
\hline 23 & Iran & 10 & 24 & 4 & 2,40 & 0 & 0 & 0 & 0 & 4 & 77.891 .220 & 0,13 & 0,31 \\
\hline 24 & Finland & 10 & 19 & 3 & 1,90 & 0 & 0 & 0 & 0 & 1 & 5.259 .250 & 1,90 & 3,61 \\
\hline 25 & Greece & 8 & 85 & 3 & 10,63 & 1 & 1 & 1 & 2 & 3 & 10.760 .136 & 0,74 & 7,90 \\
\hline 26 & Portugal & 8 & 65 & 6 & 8,13 & 0 & 0 & 0 & 3 & 6 & 10.760 .305 & 0,74 & 6,04 \\
\hline 27 & Singapore & 8 & 52 & 4 & 6,50 & 0 & 0 & 0 & 2 & 4 & 4.740 .737 & 1,69 & 10,97 \\
\hline 28 & Senegal & 6 & 26 & 4 & 4,33 & 0 & 0 & 0 & 0 & 4 & 12.643 .799 & 0,47 & 2,06 \\
\hline 29 & Pakistan & 5 & 385 & 2 & 77,00 & 1 & 1 & 1 & 2 & 2 & 187.342.721 & 0,03 & 2,06 \\
\hline 30 & Philippines & 5 & 33 & 3 & 6,60 & 0 & 0 & 0 & 1 & 3 & 101.833 .938 & 0,05 & 0,32 \\
\hline 31 & Brazil & 5 & 4 & 1 & 0,80 & 0 & 0 & 0 & 0 & 0 & 203.429.773 & 0,02 & 0,02 \\
\hline 32 & Poland & 4 & 503 & 3 & 125,75 & 2 & 2 & 2 & 2 & 2 & 38.441 .588 & 0,10 & 13,08 \\
\hline 33 & Norway & 4 & 61 & 2 & 15,25 & 0 & 1 & 1 & 1 & 1 & 4.691 .849 & 0,85 & 13,00 \\
\hline 34 & Ireland & 4 & 16 & 2 & 4,00 & 0 & 0 & 0 & 0 & 2 & 4.670 .976 & 0,86 & 3,43 \\
\hline 35 & Chile & 4 & 10 & 2 & 2,50 & 0 & 0 & 0 & 0 & 0 & 16.888 .760 & 0,24 & 0,59 \\
\hline 36 & Lebanon & 4 & 4 & 1 & 1,00 & 0 & 0 & 0 & 0 & 0 & 4.143 .101 & 0,97 & 0,97 \\
\hline 37 & South Korea & 3 & 8 & 1 & 2,67 & 0 & 0 & 0 & 0 & 1 & 48.754 .657 & 0,06 & 0,16 \\
\hline 38 & Mexico & 3 & 4 & 1 & 1,33 & 0 & 0 & 0 & 0 & 0 & 113.724 .226 & 0,03 & 0,04 \\
\hline 39 & Argentina & 3 & 4 & 2 & 1,33 & 0 & 0 & 0 & 0 & 0 & 41.769 .726 & 0,07 & 0,10 \\
\hline 40 & Georgia & 3 & 2 & 1 & 0,67 & 0 & 0 & 0 & 0 & 0 & 4.585 .874 & 0,65 & 0,44 \\
\hline
\end{tabular}

Abbreviations are available in previous tables except: Pop = Population in thousands; TS/Pop = Total studies by person multiplied by one million; TC/Pop = Total citations by person multiplied by one million.

\section{Most Influential Institutions}

Regarding the most productive institutions, 45 of the top 50 are in the USA, 2 in Israel, 2 in Canada, and 1 is in Turkey. The universities with a higher number of studies are from the USA and include the following: the Michigan State University (77), the Columbia University in the city of New York (76), the University of California, LA (68), Harvard University (63) and Ohio State University (59). The universities that follow are the University of Georgia (58), St. John's University (53), and New York University (51). As to the number of citations, the University of California ranks first with 840 citations. It is noteworthy to mention that St. John's University, which occupies the 7th position with 53 studies, is the institution of affiliation of John B. Murray, the second author with the most articles published in The Journal of Psychology according 
to Table 2. Therefore, some of these institutions may hold a high place in the list thanks to one or few authors.

Outside of the USA, institutions with greater productivity are Orta Dogu Teknik U (Turkey), in the $13^{\text {th }}$ position, and University of Calgary (Canada), in position 15 (Table 4). The University of Calgary, in Canada, ranks $15^{\text {th }}$ in the list but has more studies cited more than

Table 4. The Most Productive and Influential Institutions.

\begin{tabular}{|c|c|c|c|c|c|c|c|c|c|c|c|c|}
\hline $\mathrm{R}$ & Institution & Country & TS & TC & $\mathrm{H}$ & $\mathrm{TC} / \mathrm{TS}$ & $\geq 50$ & $\geq 25$ & $\geq 10$ & $\geq 5$ & ARWU & QS \\
\hline 1 & Michigan State U & USA & 77 & 261 & 9 & 3,39 & 0 & 0 & 9 & 21 & 99 & 160 \\
\hline 2 & Columbia U & USA & 76 & 494 & 12 & 6,50 & 2 & 6 & 14 & 24 & 8 & 20 \\
\hline 3 & U of California, LA & USA & 68 & 840 & 10 & 12,35 & 1 & 1 & 11 & 15 & 10 & 28 \\
\hline 4 & Harvard U & USA & 63 & 471 & 14 & 7,48 & 2 & 5 & 13 & 18 & 1 & 3 \\
\hline 5 & Ohio State U & USA & 59 & 241 & 7 & 4,08 & 0 & 3 & 6 & 14 & 67 & 88 \\
\hline 6 & The U of Georgia & USA & 58 & 181 & 6 & 3,12 & 1 & 2 & 5 & 9 & $151-200$ & $431-440$ \\
\hline 7 & St. John's University & USA & 53 & 402 & 11 & 7,58 & 1 & 6 & 13 & 21 & - & - \\
\hline 8 & New York U & USA & 51 & 174 & 6 & 3,41 & 1 & 1 & 6 & 8 & 27 & 46 \\
\hline 9 & The California State U & USA & 50 & 545 & 13 & 10,90 & 2 & 2 & 20 & 28 & - & - \\
\hline 10 & VA Medical Center & USA & 49 & 108 & 6 & 2,20 & 0 & 0 & 4 & 10 & - & - \\
\hline 11 & U of Rochester & USA & 47 & 62 & 5 & 1,32 & 0 & 0 & 3 & 6 & $101-150$ & 185 \\
\hline 12 & Kansas State U & USA & 46 & 271 & 9 & 5,89 & 0 & 2 & 9 & 17 & $401-500$ & $701+$ \\
\hline 13 & Orta Dogu Teknik U & Turkey & 42 & 349 & 10 & 8,31 & 0 & 2 & 12 & 24 & - & - \\
\hline 14 & Pennsylvania State U & USA & 39 & 97 & 5 & 2,49 & 0 & 0 & 4 & 6 & 60 & 95 \\
\hline 15 & U of Calgary & Canada & 38 & 463 & 12 & 12,18 & 3 & 8 & 20 & 15 & $201-300$ & 196 \\
\hline 16 & City U of NY & USA & 37 & 165 & 7 & 4,46 & 0 & 2 & 6 & 8 & $301-400$ & $501-550$ \\
\hline 17 & Purdue U & USA & 35 & 102 & 5 & 2,91 & 0 & 1 & 2 & 6 & 61 & 92 \\
\hline 18 & Stanford U & USA & 35 & 98 & 5 & 2,80 & 0 & 0 & 2 & 8 & 2 & 2 \\
\hline 19 & Bar-Ilan U & Israel & 32 & 248 & 6 & 7,75 & 1 & 2 & 6 & 13 & $401-500$ & $601-650$ \\
\hline 20 & Yale U & USA & 30 & 357 & 7 & 11,90 & 2 & 5 & 6 & 8 & 11 & 15 \\
\hline 21 & Brigham Young U & USA & 29 & 78 & 5 & 2,69 & 0 & 0 & 3 & 6 & $301-400$ & $651-700$ \\
\hline 22 & U of Maryland & USA & 28 & 101 & 6 & 3,61 & 0 & 0 & 3 & 7 & 43 & 131 \\
\hline 23 & U of North Dakota & USA & 27 & 236 & 9 & 8,74 & 1 & 2 & 7 & 13 & - & - \\
\hline 24 & U of Manitoba & Canada & 27 & 177 & 7 & 6,56 & 1 & 2 & 4 & 8 & $301-400$ & $501-550$ \\
\hline 25 & lowa State U & USA & 27 & 173 & 6 & 6,41 & 0 & 1 & 5 & 10 & $151-200$ & $421-430$ \\
\hline 26 & Tel Aviv U & Israel & 27 & 165 & 8 & 6,11 & 0 & 1 & 6 & 11 & $151-200$ & 212 \\
\hline 27 & Fordham U & USA & 27 & 139 & 7 & 5,15 & 0 & 0 & 6 & 8 & - & $701+$ \\
\hline 28 & $\mathrm{U}$ of Connecticut & USA & 27 & 132 & 7 & 4,89 & 0 & 1 & 5 & 9 & $301-400$ & $421-430$ \\
\hline 29 & Indiana U & USA & 27 & 77 & 6 & 2,85 & 0 & 0 & 2 & 8 & $201-300$ & 291 \\
\hline 30 & U of Alabama & USA & 27 & 65 & 5 & 2,41 & 0 & 0 & 3 & 5 & $201-300$ & $601-650$ \\
\hline 31 & U of Chicago & USA & 26 & 207 & 6 & 7,96 & 2 & 3 & 4 & 9 & 9 & 10 \\
\hline 32 & Virginia Commonwealth U & USA & 26 & 177 & 6 & 6,81 & 1 & 2 & 3 & 6 & $101-150$ & $651-700$ \\
\hline 33 & Ohio U & USA & 26 & 133 & 6 & 5,12 & 0 & 1 & 5 & 6 & - & $701+$ \\
\hline 34 & Utah State U & USA & 25 & 94 & 6 & 3,76 & 0 & 0 & 4 & 8 & 93 & $701+$ \\
\hline 35 & U of Missouri & USA & 24 & 103 & 5 & 4,29 & 0 & 2 & 3 & 5 & $301-400$ & $501-550$ \\
\hline 36 & Florida State U & USA & 23 & 185 & 7 & 8,04 & 1 & 1 & 6 & 10 & $201-300$ & $431-440$ \\
\hline 37 & U of Arizona & USA & 23 & 80 & 5 & 3,48 & 0 & 0 & 4 & 6 & 90 & 222 \\
\hline 38 & U of Florida & USA & 23 & 63 & 5 & 2,74 & 0 & 0 & 0 & 7 & 83 & 185 \\
\hline 39 & U of Michigan & USA & 22 & 184 & 7 & 8,36 & 1 & 2 & 6 & 9 & 22 & 23 \\
\hline 40 & U of lowa & USA & 22 & 181 & 7 & 8,23 & 1 & 1 & 5 & 8 & $151-200$ & 393 \\
\hline 41 & Temple U & USA & 22 & 112 & 5 & 5,09 & 0 & 2 & 3 & 6 & $301-400$ & $651-700$ \\
\hline 42 & Boston College & USA & 22 & 51 & 4 & 2,32 & 0 & 0 & 1 & 4 & $401-500$ & 89 \\
\hline 43 & U of Tennessee & USA & 21 & 231 & 8 & 11,00 & 0 & 4 & 6 & 14 & $151-200$ & $461-470$ \\
\hline 44 & Emory U & USA & 21 & 130 & 6 & 6,19 & 0 & 1 & 5 & 9 & $101-150$ & 149 \\
\hline 45 & The College of William and Mary & USA & 21 & 92 & 5 & 4,38 & 0 & 1 & 2 & 6 & - & $551-600$ \\
\hline 46 & Case Western Reserve U & USA & 21 & 83 & 4 & 3,95 & 0 & 1 & 1 & 4 & $101-150$ & 202 \\
\hline 47 & Marquette U & USA & 21 & 56 & 4 & 2,67 & 0 & 0 & 1 & 4 & - & $701+$ \\
\hline 48 & Northern Illinois U & USA & 21 & 12 & 6 & 0,57 & 0 & 1 & 4 & 9 & - & - \\
\hline 49 & U of Houston & USA & 20 & 130 & 6 & 6,50 & 0 & 1 & 4 & 7 & $201-300$ & $601-650$ \\
\hline 50 & U of Oklahoma & USA & 20 & 120 & 6 & 6,00 & 0 & 0 & 2 & 12 & $401-500$ & $461-470$ \\
\hline
\end{tabular}

Abbreviations are available in previous tables except: ARWU = Academic Ranking of World Universities; QS = Quacquarelli \& Symonds University Ranking. 
50 times (3), more than 25 times (8), and more than 10 times (20) than other institutions with more total studies do. These data imply a high quality and impact of the articles produced by authors in these institutions (Table 4).

The institutional contribution to the journal relates to both regional and internal university rankings according to their scientific productivity. Thus, among the ten universities with the largest number of articles published in the journal we can find Harvard University and Columbia University. They usually hold positions in the Top 10 of the Shanghai Ranking (2016), which is in an indicator of the high quality and quantity with which these institutions contribute to the growth of science.

Split rankings of Academic Ranking of World Universities (ARWU) universities uses four objective indicators: (1) number of articles published in scientific journals, especially the journals indexed in the Science Citation Index - Expanded and Social Sciences Citation Index, (2) the number of citations received by the researchers according to Thomson Reuters, and (3) the yield per capita of a university. It also includes (4) the number of graduates and researchers (Nobel prizes and Fields medals) awards. The methodology used in the ARWU is solid, stable, and transparent, hence the ARWU is a reference to describe quality and scientific productivity.

\section{Most influential institutions of each five-year period since 1936}

The Tables A.1 to A.16 in the appendix show the most influential institutions of each five-year period. This breakdown of the data allows for a more thorough assessment. The first striking fact shown by the tables is the progressive internationalization or diversification of the institutions in the ranking. While the rankings from 1936 until the 1980's show a clear predominance of American institutions, from then on, the presence of other institutions such as U. of Calgary (Canada) and Orta Dogu Teknik Universitesi or Bar-Ilan University (Israel) indicates a marked diversity regarding research origin. The second notable observation is the change in institutions appearing in the top positions. Harvard University ranks first in the first and third tables, in the second one this university ranks tenth, while it disappears altogether from 1962 onwards. The high variation in the names of the rankings since the 1960's may owe to the mentioned internationalization of the journal, but also to decisions or situations within the institutions such as the departure or retirement of a prolific scholar. Similarly, Columbia University appears in the top 11 positions until 1992, when it ceases to appear in the most influential institutions list. Finally, a third interesting observation is that of Orta Dogu Teknik Universitesi, in Turkey, which appears in the top positions since 1998. This institution has ranked first on two occasions (Tables A.7 and A.8).

\section{Mapping the Journal of Psychology with VOS Viewer Software}

In order to deepen in the analysis of the bibliographic data, this section develops a graphical visualization of the publications of The Journal of Psychology. To do so, the work uses the visualization of similarities (VOS) viewer software (Van Eck \& Waltman, 2010). This software collects the bibliographic material and develops different bibliometric techniques including co-citation of journals (Small, 1973), co-occurrence of author keywords (Laengle 


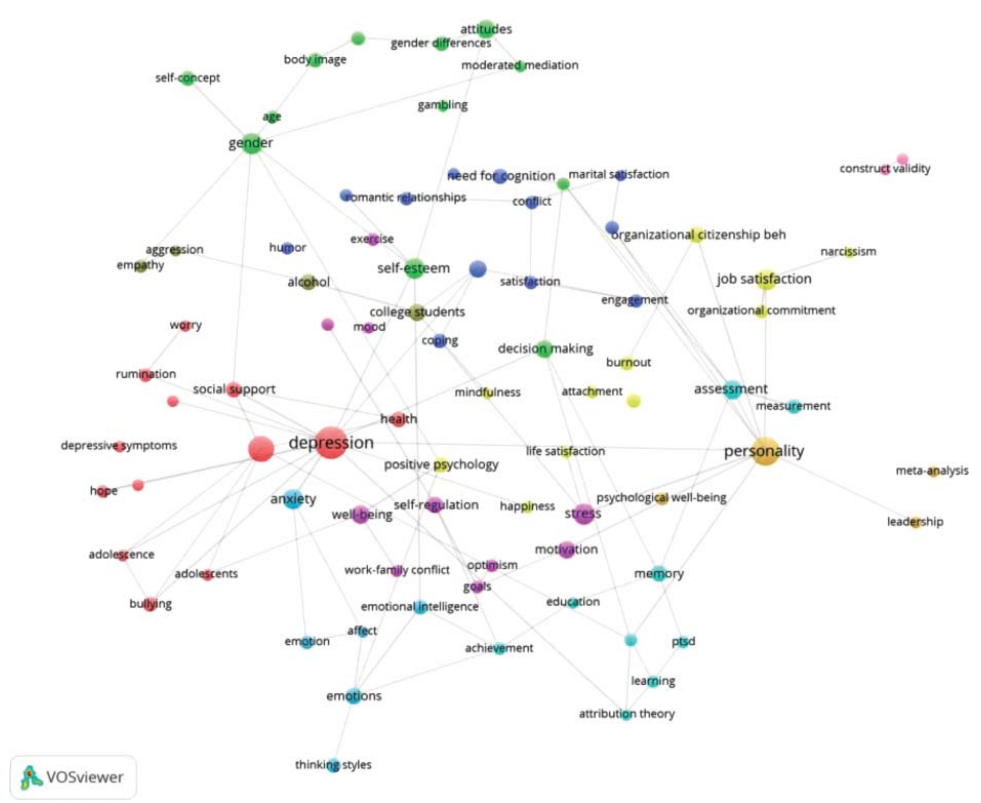

Figure 3. Co-occurrence of author keywords with a threshold of 5 documents and 100 connections.

et al., 2017) and bibliographic coupling (Kessler, 1963). Note that in this Section, for most of the figures and tables, the work uses the Web of Science database considering the publications in the journal between 1966 and 2015.

The first factor presented is co-occurrence of author keywords. The software identifies those keywords that appear more frequently in the title page of the publications of The Journal of Psychology and the network connections represents the keywords that appear more often in the same documents. Figure 3 shows that depression and personality are the two most common keywords in the journal. Most of the other keywords strongly connect with psychology also appear in the graph.

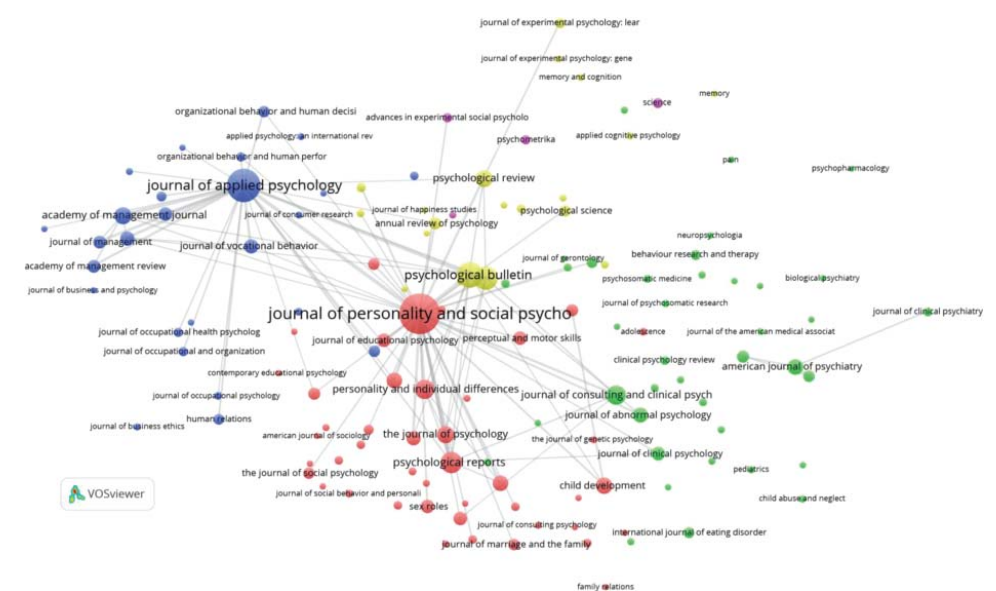

Figure 4. Co-citation of journals with a threshold of 50 citations and 100 connections. 


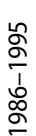

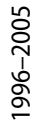
吕

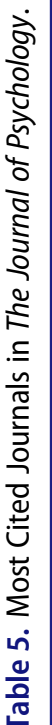

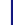

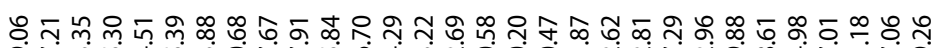

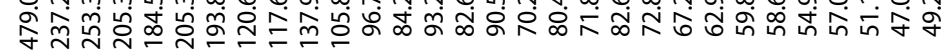

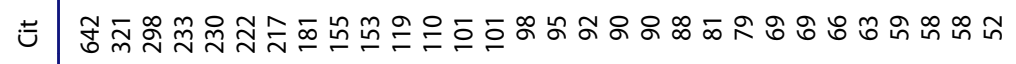
|

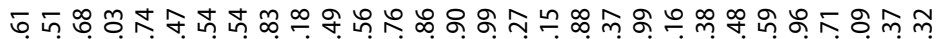
认ู่

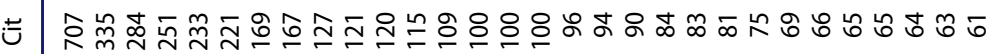

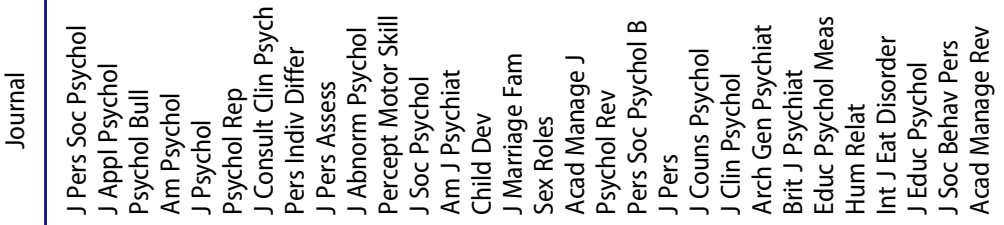

ฯ Пำ ำ

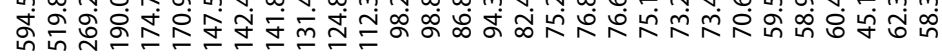

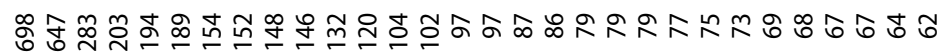

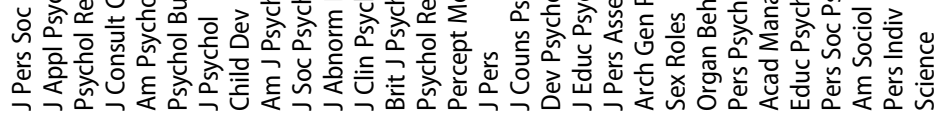

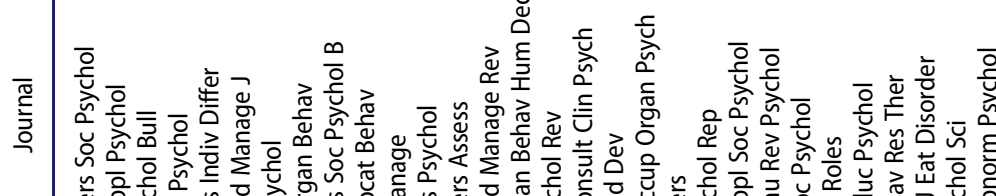
品

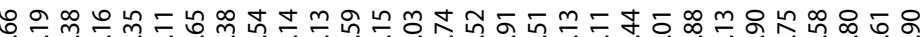

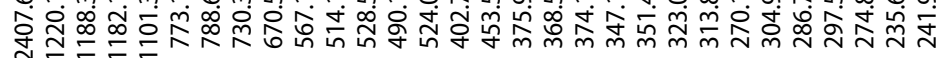

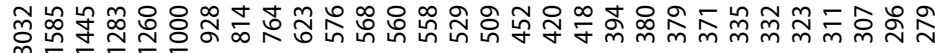


Another interesting element examined is co-citations of journals highly cited in The Journal of Psychology. Co-citation occurs when two journals receive a citation from the same document of a third journal. Figure 4 presents the co-citation network of the journal.

The Journal of Personality and Social Psychology and the Journal of Applied Psychology are the most cited journals and have the strongest network in the journal. The majority of the journals are from the psychology area although, notably, some management journals also appear in the figure. In order to obtain a more specific picture of the most cited journals in The Journal of Psychology, Table 5 presents the Top 30 considering a global perspective and the evolution over the last three decades.

The results of the table confirm the results of Figure 4. Additionally, most of the journals focus on psychology although some management journals also appear in the list, including the Journal of Management and the Academy of Management Review.

To analyze co-citation of documents, Table 6 and Figure 5 present the thirty most cited documents in the journal.

Regarding the most cited authors in the Journal of Psychology, the software develops cocitation of authors. Figure 6 presents the results considering a threshold of 50 citations and the 100 most representative connections. Note that for building this figure, the work uses the Scopus database.

Some very well-known authors in psychology appear highly cited in the journal. Among others, it is worth noting Bandura, Furnham, Beck, McRae, Ryan, and Schaufeli.

Table 6. Top 30 Most Cited Documents in The Journal of Psychology.

\begin{tabular}{|c|c|c|c|c|c|}
\hline Rank & Year & Reference & Type & $\mathrm{TC}$ & Co-Citations \\
\hline 1 & 1986 & Baron RM, J Pers Soc Psychol, V51, P1173 & A & 60 & 39 \\
\hline 2 & 1965 & Rosenberg M, Soc Adolescent Self & B & 58 & 34 \\
\hline 3 & 1957 & Osgood C, Measurement Meaning & B & 53 & 22 \\
\hline 4 & 1966 & Rotter JB, Psychol Monog, V80 & A & 53 & 18 \\
\hline 5 & 1962 & Winer BJ, Statistical Principl & B & 47 & 5 \\
\hline 6 & 1960 & Rokeach M, Open Closed Mind & B & 40 & 24 \\
\hline 7 & 1991 & Aiken LS, Multiple Regression & B & 39 & 28 \\
\hline 8 & 1971 & Winer BJ, Statistical Principl & B & 38 & 10 \\
\hline 9 & 1950 & Adorno TW, Authoritarian Person & B & 36 & 22 \\
\hline 10 & 1956 & Siegel S, Nonparametric Statis & B & 33 & 13 \\
\hline 11 & 1974 & Bem SL, J Consult Clin Psych, V42, P155 & A & 32 & 8 \\
\hline 12 & 1957 & Festinger L, Theory Cognitive Dis & B & 32 & 14 \\
\hline 13 & 1958 & Kaiser HF, Psychometrika, V23, P187 & A & 31 & 14 \\
\hline 14 & 1967 & Coopersmith S, Antecedents Self Est & B & 30 & 13 \\
\hline 15 & 1984 & Lazarus RS, Stress Appraisal Cop & B & 30 & 22 \\
\hline 16 & 1985 & Diener E, J Pers Assess, V49, P71 & A & 29 & 24 \\
\hline 17 & 1960 & Crowne DP, J Consult Psychol, V24, P349 & A & 28 & 10 \\
\hline 18 & 1978 & Nunnally JC, Psychometric Theory & B & 28 & 22 \\
\hline 19 & 1953 & Taylor JA, J Abnorm Soc Psych, V48, P285 & A & 28 & 9 \\
\hline 20 & 1966 & Rotter JB, Psychol Monographs, V80 & A & 27 & 16 \\
\hline 21 & 1988 & Cohen J, Stat Power Anal Beha & B & 25 & 14 \\
\hline 22 & 1958 & Heider F, Psychol Interpersona & B & 24 & 10 \\
\hline 23 & 1966 & Cattell RB, Multivar Behav Res, V1, P245 & A & 23 & 12 \\
\hline 24 & 1964 & Crowne DP, Approval Motive & B & 23 & 12 \\
\hline 25 & 1972 & Dion K, J Pers Soc Psychol, V24, P285 & A & 23 & 4 \\
\hline 26 & 1997 & Bandura A, Self Efficacy Exerci & B & 22 & 12 \\
\hline 27 & 1999 & Hu LT, Struct Equ Modeling, V6, P1 & A & 22 & 17 \\
\hline 28 & 1968 & Kirk RE, Expt Design Procedur & B & 22 & 5 \\
\hline 29 & 1953 & McClelland DC, Achievement Motive & B & 22 & 17 \\
\hline 30 & 1988 & Watson D, J Pers Soc Psychol, V54, P1063 & A & 22 & 15 \\
\hline
\end{tabular}

Abbreviations available in previous tables. 


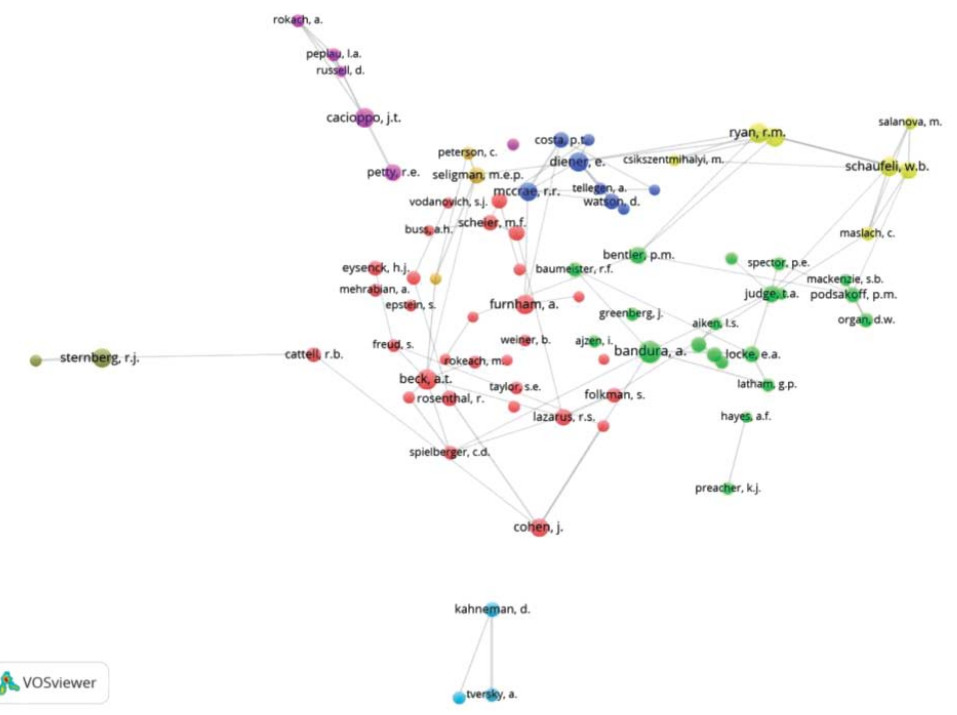

Figure 5. Co-citation of authors with a threshold of 50 citations and 100 connections.

Finally, let us develop a graphical visualization of the most productive institutions. For doing so, the study uses bibliographic coupling between institutions. Recall that bibliographic coupling, (Kessler, 1963) of institutions occur when two documents of different institutions cite the same third document of another university. Figure 6 shows the results.

The results are consistent with those of Table 4 although the figure visualizes how the institutions are connected between each other. Particularly, it is worth noting that

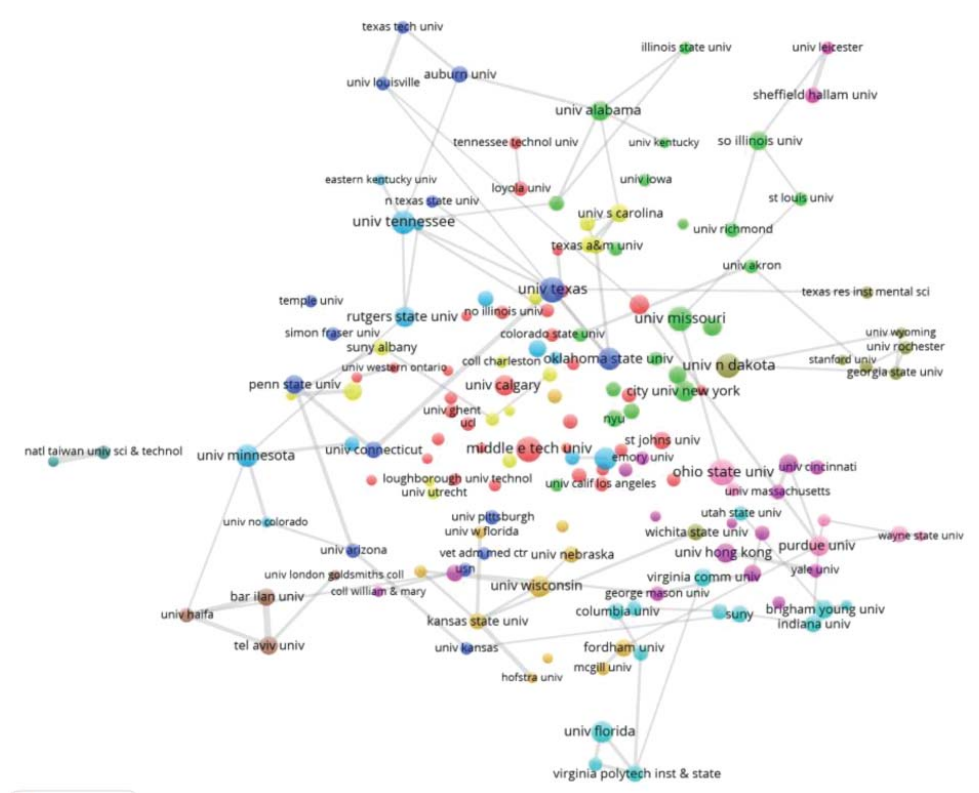

A vosviewer

Figure 6. Bibliographic coupling of universities with a threshold of 5 documents and 100 connections. 
institutions from the same country tend to be more close to each other due to co-authorship and a research profile that follows similar patterns.

\section{Conclusions}

This article provides a bibliographic overview of the research published in The Journal of Psychology: Interdisciplinary and Applied throughout its long tenure, starting from the data gathered from Scopus and the use of bibliometric indicators. The results show that The Journal of Psychology has gone through different stages. The first stage (until 1962) captured the period in which the number of publications and their impact on the scientific community was modest, with the exception of the year 1946. That year Heider published his article on "Attitudes and cognitive organization," which has received over a thousand citations. The second stage (1962-1984) was a period in which the number of publications from the journal increased considerably. The third stage, from 1985 to 2002 was a period in which the number of publications decreased slightly, but a growing trend emerges regarding the number of citations. During this stage, there are fewer articles with more than 75 citations, but the groups from 25 to 74 citations increases significantly (136). This is important because it denotes some dispersion concerning the weight of the citations.

From 2003 on, the outcome noticeably changes; that is, the total number of published articles diminishes, but the number of citations is maintained (not counting the three most current years). 2009 is a notable exception; with more than 1500 citations being reported. That year (2009) two articles on bullying and cyberbullying were published, both receiving great acceptance: one written by Dooley, Pyzalski and Cross (2009), and the other by Gradinger, Strohmeier and Spiel (2009).

Analysis of the institutions and countries has shown that American universities are leading publishers in the journal, followed by the UK and Australia, all of them predominantly English-speaking countries. In recent years, however, there has been an expansion of universities and countries, giving coverage to research from institutions located in the Middle East (Israel, Pakistan, Lebanon, etc.), Europe (Germany, Netherlands, Turkey, Italy, Sweden, Belgium, Switzerland, France, Spain, etc.) countries in Southeast Asia (China, Taiwan, Japan, India, New Zealand, etc.), African countries (South Africa, Nigeria, Senegal, etc.) and countries in South America (Chile, Argentina, Mexico, etc.). The increase in the diversity of institutional representation is a reflection of the increased expansion of research in other parts of the world.

Results from the bibliographic examination revealed that, there is a core/nucleus composed of the 10 most cited authors whose articles receive roughly $50 \%$ of the citations of the journal. A large amount of citations depends on few articles and a large number of articles receive the same number of citations than the core which is rather low.

Finally, this bibliometric analysis of the journal has some limitations that should be noted. First, research in psychology is very broad and interdisciplinary, and although the journal is interdisciplinary, publishing a diverse number of topics, not all of them are reflected in the journal. Second, this bibliometric analysis gives every author a unit just as Scopus does. Therefore, the articles signed by several authors have better results. For example, two articles with four signatories provide two units to each of them, with a result of eight. Thus, from 
this example, the number of signatories leads to a better outcome. However, in general, this issue does not significantly affect the results. Thirdly, the increase in citations within the last few years is a reflection of the overall growing condition of the journal. Widespread access to documental sources through the internet (e.g., Web of Science, ProQuest, Scopus, PsycINFO PubMed, MEDLINE, Current Contents, among others) facilitates the spread and the knowledge of research conducted by the researchers themselves. Despite these limitations, this bibliometric analysis identifies the most influential trends presented in The Journal of Psychology, and should prove valuable to potential authors and the journal's general readership.

\section{Author Notes}

Ana Tur-Porcar is an associate professor at the University of Valencia. Her research is focused on personality, prosocial behavior, entrepreneurship and emotions. She has published papers in journals such as the Journal of Business Research, Personality and Individual Differences, the Journal of Adolescence, Psychology \& Marketing, Quality \& Quantity and the Journal of Cross-Cultural Psychology. She is or has been on the editorial board, guest editor and referee of several indexed journals.

Alicia Mas-Tur is a lecturer in the Management Department at the University of Valencia. She has presented numerous papers at international conferences. She has also published articles and books in international journals including Service Industries Journal, International Entrepreneurship and Management Journal, and Service Business. She is or has been the guest editor and referee for international journals. She is or has been on the editorial board of several journals including the Journal of Business Research and Contemporary Economics.

José M. Merigó is a professor at the Department of Management Control and Information Systems at the University of Chile. He has published more than 400 papers in journals, books and conference proceedings. He is or has been on the editorial board of several journals including the Journal of Business Research, Technological and Economic Development of Economy and Journal of Intelligent \& Fuzzy Systems. He has been recognized as a Highly Cited Author in Computer Science by Clarivate Analytics (Thomson \& Reuters).

Norat Roig-Tierno is a professor at the ESIC Business \& Marketing School and the Polytechnic University of Valencia. He has presented numerous papers at international conferences. He has published articles and books in international journals including Service Industries Journal, Journal of Business Research, and Applied Geography. He is or has been on the editorial board of several journals including the Journal of Business Research and Journal of Innovation and Knowledge.

John Watt is a clinical associate professor of management at Texas A\&M University. He is responsible for teaching undergraduate and graduate courses in Creativity and Innovation, Organizational Behavior/Management, and Leadership. He is Executive Editor of The Journal of Psychology: Interdisciplinary and Applied. He has published articles and books in international journals including Journal of Applied Psychology, Journal of College Student Development and Journal of Research in Personality.

\section{References}

Bonilla, C., Merigó, J. M., \& Torres-Abad, C. (2015). Economics in Latin America: A bibliometric analysis. Scientometrics, 105, 1239-1252.

Carleton, R. N., Parkerson, H. A., \& Horswill, S. C. (2012). Assessing the publication productivity of clinical psychology professors in Canadian Psychological Association-accredited Canadian psychology departments. Canadian Psychology/Psychologie Canadienne, 53(3), 226. 
Coupé, T. (2003). Revealed performances: Worldwide rankings of economists and economics departments, 1990-2000. Journal of the European Economic Association, 1(6), 1309-1345.

Dooley, J. J., Pyżalski, J., \& Cross, D. (2009). Cyberbullying versus face-to-face bullying: A theoretical and conceptual review. Zeitschrift für Psychologie/Journal of Psychology, 217(4), 182-188.

Egghe, L. (2006). Theory and practise of the g-index. Scientometrics, 69(1), 131-152.

Fagerberg, J., Fosaas, M., \& Sapprasert, K. (2012). Innovation: Exploring the knowledge base. Research Policy, 41(7), 1132-1153.

Feist, G. J. (1997). Quantity, quality, and depth of research as influences on scientific eminence: Is quantity most important? Creativity Research Journal, 10(4), 325-335.

Gradinger, P., Strohmeier, D., \& Spiel, C. (2009). Traditional bullying and cyberbullying: Identification of risk groups for adjustment problems. Zeitschrift für Psychologie/Journal of Psychology, 217(4), 205-213.

Harzing, A. W. (2010). The Publish or Perish book: Your guide to effective and responsible citation analysis. Melbourne, Australia: Tarma Software Research Pty Ltd.

Harzing, A. W., Alakangas, S., \& Adams, D. (2014). HLA: An individual annual h-index to accommodate disciplinary and career length differences. Scientometrics, 99(3), 811-821.

Heider, F. (1946). Attitudes and cognitive organization. The Journal of psychology, 21(1), 107-112.

Heider, F. (1958). The psychology of interpersonal relations. Mahwah, NJ: Lawrence Erlbaum Associates. Inc.

Hirsch, J. E. (2005). An index to quantify an individual's scientific research output. Proceedings of the National academy of Sciences of the United States of America, 102(46), 16569.

Kessler, M. M. (1963). Bibliographic coupling between scientific papers. Journal of the Association for Information Science and Technology, 14(1), 10-25.

Krampen, G., Becker, R., Wahner, U., \& Montada, L. (2007). On the validity of citation counting in science evaluation: Content analyses of references and citations in psychological publications. Scientometrics, 71(2), 191-202.

Laengle, S., Merigó, J. M., Miranda, J., Słowiński, R., Bomze, I., Borgonovo, E., ... \& Teunter, R. (2017). Forty years of the European Journal of Operational Research: A bibliometric overview. European Journal of Operational Research, 262(3), 803-816.

Landström, H., Harirchi, G., \& Aström, F. (2012). Entrepreneurship: Exploring the knowledge base. Research Policy, 41(7), 1154-1181.

Merigó, J. M., Blanco-Mesa, F., Gil-Lafuente, A. M., \& Yager, R. R. (2017). Thirty years of the International Journal of Intelligent Systems: A bibliometric review. International Journal of Intelligent Systems, 32(5), 526-554.

Merigó, J. M., Gil-Lafuente, A. M., \& Yager, R. R. (2015). An overview of fuzzy research with bibliometric indicators. Applied Soft Computing, 27, 420-433.

Merigó, J. M., Mas-Tur, A., Roig-Tierno, N., \& Ribeiro-Soriano, D. (2015). A bibliometric overview of the Journal of Business Research between 1973 and 2014. Journal of Business Research, 68(12), 2645-2653.

Paolucci, E. O., Genuis, M. L., \& Violato, C. (2001). A meta-analysis of the published research on the effects of child sexual abuse. The Journal of Psychology, 135(1), 17-36.

Podsakoff, P. M., MacKenzie, S. B., Podsakoff, N. P., \& Bachrach, D. G. (2008). Scholarly influence in the field of management: A bibliometric analysis of the determinants of university and author impact in the management literature in the past quarter century. Journal of Management, 34(4), 641-720.

Reuters, T. (2015). InCites ${ }^{\mathrm{TM}}$ Journal Citation Reports ${ }^{\circledR}$. Web of Science.

Shanghai Ranking (2016). Academic Ranking of World Universities. http://www.shanghairanking.com/ ARWU2016.html

Small, H. (1973). Co-citation in the scientific literature: A new measure of the relationship between two documents. Journal of the Association for Information Science and Technology, 24(4), 265-269.

Stogdill, R. M. (1948). Personal factors associated with leadership: A survey of the literature. The Journal of psychology, 25(1), 35-71. 
Valenzuela, L. M., Merigó, J. M., Johnston, W. J., Nicolas, C., \& Jaramillo, J. F. (2017). Thirty years of the Journal of Business \& Industrial Marketing: A bibliometric analysis. Journal of Business \& Industrial Marketing, 32(1), 1-17.

Van Eck, N. J., \& Waltman, L. (2010). Software survey: VOSviewer, a computer program for bibliometric mapping. Scientometrics, 84(2), 523-538.

Wagstaff, A., \& Culyer, A. J. (2012). Four decades of health economics through a bibliometric lens. Journal of Health Economics, 31(2), 406-439.

\section{Appendix}

Temporal Evolution of the Most Productive Institutions in The Journal of Psychology

Table A1. Period 1936-1949.

\begin{tabular}{|c|c|c|c|c|c|}
\hline \multicolumn{6}{|c|}{ 1936-1949 } \\
\hline $\mathrm{R}$ & Institution & TS & $\mathrm{TC}$ & $\mathrm{H}$ & $\mathrm{TC} / \mathrm{TS}$ \\
\hline 1 & Harvard U & 43 & 356 & 7 & 8,28 \\
\hline 2 & Columbia $\mathrm{U}$ in the City of NY & 37 & 225 & 6 & 6,08 \\
\hline 3 & Ohio State University & 17 & 54 & 2 & 3,18 \\
\hline 4 & Stanford University & 16 & 22 & 3 & 1,38 \\
\hline 5 & Howard University & 12 & 19 & 2 & 1,58 \\
\hline 6 & Northwestern University & 11 & 23 & 3 & 2,09 \\
\hline 7 & Yale U & 10 & 179 & 3 & 17,90 \\
\hline 8 & Princeton University & 10 & 23 & 2 & 2,30 \\
\hline 9 & Wesleyan University Middletown & 9 & 38 & 5 & 4,22 \\
\hline 10 & University of Illinois & 9 & 26 & 4 & 2,89 \\
\hline 11 & Case Western Reserve U & 9 & 20 & 3 & 2,22 \\
\hline 12 & University of lowa & 8 & 26 & 3 & 3,25 \\
\hline 13 & U of California, LA & 8 & 0 & 0 & 0,00 \\
\hline 14 & Connecticut College & 7 & 19 & 3 & 2,71 \\
\hline 15 & Yale Laboratories of Primate Biology & 7 & 14 & 2 & 2,00 \\
\hline 16 & Hunter College & 7 & 11 & 2 & 1,57 \\
\hline 17 & University of Rochester & 7 & 7 & 1 & 1,00 \\
\hline 18 & New York University & 6 & 18 & 1 & 3,00 \\
\hline 19 & Syracuse University & 6 & 17 & 3 & 2,83 \\
\hline 20 & Wellesley College & 6 & 16 & 2 & 2,67 \\
\hline 21 & University of Southern California & 6 & 13 & 2 & 2,17 \\
\hline 22 & The Lifwynn Foundation & 5 & 2 & 1 & 0,40 \\
\hline 23 & University of Georgia & 5 & 2 & 1 & 0,40 \\
\hline 24 & College of the City of New York & 5 & 1 & 1 & 0,20 \\
\hline 25 & Los Angeles City College & 5 & 0 & 0 & 0,00 \\
\hline 26 & Smith College & 4 & 211 & 1 & 52,75 \\
\hline 27 & Western State Psychiatric Institute and Clinic & 4 & 28 & 2 & 7,00 \\
\hline 28 & New York Psychiatric Institute & 4 & 19 & 2 & 4,75 \\
\hline 29 & University of Michigan & 4 & 3 & 1 & 0,75 \\
\hline 30 & Harvard Psychological Clinic & 4 & 0 & 0 & 0,00 \\
\hline
\end{tabular}


Table A2. Period 1950-1959.

\begin{tabular}{|c|c|c|c|c|c|}
\hline \multicolumn{6}{|c|}{ 1950-1959 } \\
\hline $\mathrm{R}$ & Institution & TS & $\mathrm{TC}$ & $\mathrm{H}$ & $\mathrm{TC} / \mathrm{TS}$ \\
\hline 1 & Michigan State University & 20 & 61 & 4 & 3,05 \\
\hline 2 & University of Rochester & 18 & 15 & 2 & 0,83 \\
\hline 3 & Columbia University in the City of NY & 17 & 133 & 6 & 7,82 \\
\hline 4 & New York University & 16 & 118 & 4 & 7,38 \\
\hline 5 & Harvard University & 13 & 119 & 4 & 9,15 \\
\hline 6 & Indiana University & 12 & 29 & 4 & 2,42 \\
\hline 7 & University of California, LA & 11 & 57 & 4 & 5,18 \\
\hline 8 & Clark University & 10 & 43 & 4 & 4,30 \\
\hline 9 & Tufts University & 10 & 25 & 3 & 2,50 \\
\hline 10 & VA Medical Center & 10 & 24 & 2 & 2,40 \\
\hline 11 & Stanford University & 10 & 22 & 2 & 2,20 \\
\hline 12 & Johns Hopkins University & 9 & 98 & 3 & 10,89 \\
\hline 13 & The Mount Sinai Hospital & 9 & 56 & 3 & 6,22 \\
\hline 14 & University of Connecticut & 8 & 43 & 4 & 5,38 \\
\hline 15 & Brandeis University & 7 & 9 & 1 & 1,29 \\
\hline 16 & Long Island University & 7 & 8 & 1 & 1,14 \\
\hline 17 & University of Chicago & 6 & 87 & 4 & 14,50 \\
\hline 18 & Purdue University & 6 & 22 & 3 & 3,67 \\
\hline 19 & George Washington University & 6 & 0 & 0 & 0,00 \\
\hline 20 & Yale University & 5 & 107 & 3 & 21,40 \\
\hline 21 & Miami University & 5 & 53 & 3 & 10,60 \\
\hline 22 & The Menninger Foundation & 5 & 46 & 2 & 9,20 \\
\hline 23 & Northwestern University & 5 & 35 & 4 & 7,00 \\
\hline 24 & Massachusetts Institute of Technology & 5 & 31 & 2 & 6,20 \\
\hline 25 & University of Michigan & 4 & 22 & 3 & 5,50 \\
\hline 26 & Boston University & 5 & 13 & 2 & 2,60 \\
\hline 27 & Psychiatric Institute & 5 & 12 & 2 & 2,40 \\
\hline 28 & Pennsylvania State University & 5 & 9 & 2 & 1,80 \\
\hline 29 & Brooklyn College & 5 & 2 & 1 & 0,40 \\
\hline 30 & University of California, Santa Barbara & 5 & 2 & 1 & 0,40 \\
\hline
\end{tabular}


Table A3. Period 1960-1969.

\begin{tabular}{|c|c|c|c|c|c|}
\hline \multicolumn{6}{|c|}{ 1960-1969 } \\
\hline $\mathrm{R}$ & Institution & TS & TC & $\mathrm{H}$ & $\mathrm{TC} / \mathrm{TS}$ \\
\hline 1 & Michigan State University & 32 & 67 & 5 & 2,09 \\
\hline 2 & University of Georgia & 21 & 54 & 4 & 2,57 \\
\hline 3 & VA Medical Center & 20 & 41 & 3 & 2,05 \\
\hline 4 & University of Rochester & 15 & 3 & 1 & 0,20 \\
\hline 5 & New York University & 14 & 8 & 2 & 0,57 \\
\hline 6 & Boston College & 13 & 22 & 2 & 1,69 \\
\hline 7 & Ohio State University & 12 & 18 & 3 & 1,50 \\
\hline 8 & City University of New York & 11 & 61 & 3 & 5,55 \\
\hline 9 & University of Calgary & 10 & 98 & 3 & 9,80 \\
\hline 10 & University of California, Los Angeles & 10 & 82 & 3 & 8,20 \\
\hline 11 & Pennsylvania State University & 10 & 20 & 2 & 2,00 \\
\hline 12 & University of Bridgeport & 10 & 14 & 2 & 1,40 \\
\hline 13 & University of Alabama & 9 & 5 & 1 & 0,56 \\
\hline 14 & Ohio University & 9 & 1 & 1 & 0,11 \\
\hline 15 & University of Maryland & 8 & 22 & 3 & 2,75 \\
\hline 16 & University of Manitoba & 8 & 16 & 2 & 2,00 \\
\hline 17 & Columbia University in the City of NY & 7 & 16 & 3 & 2,29 \\
\hline 18 & California State College at Los Angeles & 7 & 7 & 1 & 1,00 \\
\hline 19 & University of Kentucky & 7 & 3 & 1 & 0,43 \\
\hline 20 & University of Wisconsin & 7 & 2 & 1 & 0,29 \\
\hline 21 & Louisiana State University & 7 & 1 & 1 & 0,14 \\
\hline 22 & Wellesley College & 6 & 56 & 1 & 9,33 \\
\hline 23 & Case Western Reserve University & 6 & 51 & 1 & 8,50 \\
\hline 24 & Yale University & 5 & 46 & 2 & 9,20 \\
\hline 25 & University of Árizona & 6 & 14 & 3 & 2,33 \\
\hline 26 & University of Southern California & 6 & 14 & 2 & 2,33 \\
\hline 27 & Purdue Úniversity & 6 & 11 & 3 & 1,83 \\
\hline 28 & University of lowa & 6 & 11 & 2 & 1,83 \\
\hline 29 & Rutgers, The State University of New Jersey & 6 & 10 & 2 & 1,67 \\
\hline 30 & University of Utah & 6 & 1 & 1 & 0,17 \\
\hline
\end{tabular}


Table A4. Period 1970-1979.

\begin{tabular}{|c|c|c|c|c|c|}
\hline \multicolumn{6}{|c|}{ 1970-1979 } \\
\hline $\mathrm{R}$ & Institution & TS & $\mathrm{TC}$ & $\mathrm{H}$ & $\mathrm{TC} / \mathrm{TS}$ \\
\hline 1 & University of Georgia & 30 & 129 & 7 & 4,30 \\
\hline 2 & UC Berkeley & 20 & 117 & 6 & 5,85 \\
\hline 3 & University of California, Los Angeles & 20 & 94 & 5 & 4,70 \\
\hline 4 & University of Texas at Austin & 19 & 119 & 5 & 6,26 \\
\hline 5 & University of Manitoba & 17 & 109 & 6 & 6,41 \\
\hline 6 & University of Wisconsin Madison & 17 & 83 & 6 & 4,88 \\
\hline 7 & University of Florida & 17 & 76 & 7 & 4,47 \\
\hline 8 & Brigham Young University & 16 & 46 & 3 & 2,88 \\
\hline 9 & Virginia Commonwealth University & 16 & 41 & 4 & 2,56 \\
\hline 10 & Ohio State University & 16 & 38 & 4 & 2,38 \\
\hline 11 & University of Pennsylvania & 15 & 173 & 7 & 11,53 \\
\hline 12 & Purdue University & 14 & 43 & 4 & 3,07 \\
\hline 13 & University of Arizona & 13 & 281 & 7 & 21,62 \\
\hline 14 & University of Calgary & 13 & 172 & 5 & 13,23 \\
\hline 15 & VA Medical Center & 13 & 49 & 3 & 3,77 \\
\hline 16 & University of Kentucky & 13 & 47 & 4 & 3,62 \\
\hline 17 & New York University & 13 & 47 & 5 & 3,62 \\
\hline 18 & Pennsylvania State University & 13 & 24 & 3 & 1,85 \\
\hline 19 & University of Maryland & 12 & 46 & 3 & 3,83 \\
\hline 20 & Michigan State University & 12 & 33 & 3 & 2,75 \\
\hline 21 & City University of New York & 12 & 17 & 2 & 1,42 \\
\hline 22 & Temple University & 11 & 36 & 3 & 3,27 \\
\hline 23 & Rutgers, The State University of New Jersey & 10 & 72 & 5 & 7,20 \\
\hline 24 & Yale University & 10 & 69 & 3 & 6,90 \\
\hline 25 & Texas $A$ and $M$ University & 10 & 67 & 3 & 6,70 \\
\hline 26 & University of Missouri-Columbia & 10 & 30 & 3 & 3,00 \\
\hline 27 & Utah State University & 10 & 29 & 2 & 2,90 \\
\hline 28 & Indiana University & 10 & 20 & 3 & 2,00 \\
\hline 29 & New Mexico State University Las Cruces & 9 & 20 & 3 & 2,22 \\
\hline 30 & Arizona State University & 9 & 15 & 2 & 1,67 \\
\hline
\end{tabular}


Table A5. Period 1980-1989.

\begin{tabular}{|c|c|c|c|c|c|}
\hline \multicolumn{6}{|c|}{ 1980-1989 } \\
\hline $\mathrm{R}$ & Institution & TS & $\mathrm{TC}$ & $\mathrm{H}$ & $\mathrm{TC} / \mathrm{TS}$ \\
\hline 1 & University of Texas at Austin & 25 & 144 & 7 & 5,76 \\
\hline 2 & Pennsylvania State University & 21 & 54 & 5 & 2,57 \\
\hline 3 & Texas $A$ and $M$ University & 20 & 332 & 10 & 16,60 \\
\hline 4 & University of Nebraska - Lincoln & 19 & 375 & 12 & 19,74 \\
\hline 5 & Louisiana State University & 18 & 553 & 11 & 30,72 \\
\hline 6 & California State University & 18 & 171 & 7 & 9,50 \\
\hline 7 & University of Arizona & 18 & 112 & 6 & 6,22 \\
\hline 8 & Kansas State University & 17 & 51 & 5 & 3,00 \\
\hline 9 & The University of Georgia & 16 & 141 & 7 & 8,81 \\
\hline 10 & lowa State University & 14 & 145 & 5 & 10,36 \\
\hline 11 & Florida State University & 13 & 179 & 6 & 13,77 \\
\hline 12 & Ohio State University & 13 & 164 & 6 & 12,62 \\
\hline 13 & University of Wisconsin Madison & 13 & 162 & 7 & 12,46 \\
\hline 14 & University of Alabama & 12 & 174 & 7 & 14,50 \\
\hline 15 & Arizona State University & 12 & 64 & 5 & 5,33 \\
\hline 16 & Rutgers, The State University of New Jersey & 11 & 90 & 5 & 8,18 \\
\hline 17 & University of Cincinnati & 10 & 86 & 5 & 8,60 \\
\hline 18 & University of North Carolina at Chapel Hill & 10 & 59 & 5 & 5,90 \\
\hline 19 & Universite Laval & 9 & 124 & 5 & 13,78 \\
\hline 20 & University of Florida & 9 & 87 & 6 & 9,67 \\
\hline 21 & University of Maryland & 9 & 57 & 4 & 6,33 \\
\hline 22 & Tel Aviv University & 9 & 42 & 4 & 4,67 \\
\hline 23 & Catholic University of America & 9 & 33 & 4 & 3,67 \\
\hline 24 & University of Alberta & 8 & 111 & 5 & 13,88 \\
\hline 25 & University of Southern Mississippi & 8 & 62 & 4 & 7,75 \\
\hline 26 & University of North Carolina at Greensboro & 8 & 51 & 4 & 6,38 \\
\hline 27 & Fordham University & 8 & 50 & 4 & 6,25 \\
\hline 28 & New York University & 8 & 29 & 3 & 3,63 \\
\hline 29 & Columbia University in the City of New York & 8 & 21 & 3 & 2,63 \\
\hline 30 & American University of Beirut & 8 & 20 & 4 & 2,50 \\
\hline
\end{tabular}


Table A6. Period 1990-1999.

\begin{tabular}{|c|c|c|c|c|c|}
\hline \multicolumn{6}{|c|}{ 1990-1999 } \\
\hline $\mathrm{R}$ & Institution & TS & $\mathrm{TC}$ & $\mathrm{H}$ & $\mathrm{TC} / \mathrm{TS}$ \\
\hline 1 & University of Wisconsin Madison & 18 & 791 & 14 & 43,94 \\
\hline 2 & St. John's University & 15 & 122 & 4 & 8,13 \\
\hline 3 & University of Nebraska - Lincoln & 14 & 390 & 10 & 27,86 \\
\hline 4 & Texas $\mathrm{A}$ and $\mathrm{M}$ University & 13 & 269 & 9 & 20,69 \\
\hline 5 & Bar-Ilan University & 13 & 173 & 5 & 13,31 \\
\hline 6 & California State University & 12 & 170 & 5 & 14,17 \\
\hline 7 & Ohio State University & 12 & 103 & 7 & 8,58 \\
\hline 8 & Northern Illinois University & 11 & 119 & 5 & 10,82 \\
\hline 9 & University of Texas at Austin & 10 & 92 & 6 & 9,20 \\
\hline 10 & Ulster University & 10 & 46 & 4 & 4,60 \\
\hline 11 & The College of William and Mary & 10 & 20 & 2 & 2,00 \\
\hline 12 & Western Michigan University & 9 & 391 & 3 & 43,44 \\
\hline 13 & Mississippi State University & 9 & 391 & 3 & 43,44 \\
\hline 14 & University of Connecticut & 9 & 122 & 5 & 13,56 \\
\hline 15 & Michigan State University & 9 & 63 & 5 & 7,00 \\
\hline 16 & Pennsylvania State University & 8 & 191 & 5 & 23,88 \\
\hline 17 & University of Georgia & 8 & 154 & 6 & 19,25 \\
\hline 18 & Columbia University in the City of NY & 8 & 110 & 5 & 13,75 \\
\hline 19 & Lehigh University & 8 & 104 & 7 & 13,00 \\
\hline 20 & University of Nebraska at Omaha & 8 & 87 & 4 & 10,88 \\
\hline 21 & Tel Aviv Unniversity & 8 & 50 & 4 & 6,25 \\
\hline 22 & Ball State University & 8 & 40 & 4 & 5,00 \\
\hline 23 & University of Pennsylvania & 7 & 195 & 5 & 27,86 \\
\hline 24 & City University of New York & 7 & 57 & 3 & 8,14 \\
\hline 25 & Lewis University & 7 & 42 & 3 & 6,00 \\
\hline 26 & University of Alaska Anchorage & 7 & 36 & 3 & 5,14 \\
\hline 27 & University of Newcastle, Australia & 7 & 13 & 3 & 1,86 \\
\hline 28 & lowa State University & 6 & 100 & 3 & 16,67 \\
\hline 29 & Orta Dogu Teknik Universitesi & 6 & 97 & 4 & 16,17 \\
\hline 30 & Vanderbilt University & 6 & 34 & 2 & 5,67 \\
\hline
\end{tabular}


Table A7. Period 2000-2009.

\begin{tabular}{|c|c|c|c|c|c|}
\hline \multicolumn{6}{|c|}{ 2000-2009 } \\
\hline $\mathrm{R}$ & Institution & TS & $\mathrm{TC}$ & $\mathrm{H}$ & $\mathrm{TC} / \mathrm{TS}$ \\
\hline 1 & Orta Dogu Teknik Universitesi & 17 & 94 & 7 & 5,53 \\
\hline 2 & Texas $\mathrm{A}$ and $\mathrm{M}$ University & 14 & 601 & 12 & 42,93 \\
\hline 3 & University of North Dakota & 14 & 122 & 6 & 8,71 \\
\hline 4 & University of Wisconsin Madison & 12 & 617 & 12 & 51,42 \\
\hline 5 & Pennsylvania State University & 11 & 324 & 8 & 29,45 \\
\hline 6 & University of Minnesota Twin Cities & 10 & 492 & 9 & 49,20 \\
\hline 7 & University of North Carolina at Chapel Hill & 9 & 848 & 8 & 94,22 \\
\hline 8 & University of Virginia & 9 & 610 & 8 & 67,78 \\
\hline 9 & Florida State University & 9 & 467 & 8 & 51,89 \\
\hline 10 & University of Hong Kong & 9 & 246 & 8 & 27,33 \\
\hline 11 & University of Tennessee at Chattanooga & 9 & 163 & 6 & 18,11 \\
\hline 12 & Georgia State University & 8 & 380 & 7 & 47,50 \\
\hline 13 & Lehigh University & 8 & 250 & 8 & 31,25 \\
\hline 14 & University of Georgia & 8 & 209 & 6 & 26,13 \\
\hline 15 & Loughborough University & 8 & 81 & 6 & 10,13 \\
\hline 16 & Kansas State University & 8 & 64 & 5 & 8,00 \\
\hline 17 & California State University & 8 & 61 & 5 & 7,63 \\
\hline 18 & University of Nebraska - Lincoln & 7 & 292 & 6 & 41,71 \\
\hline 19 & University of Houston & 7 & 199 & 5 & 28,43 \\
\hline 20 & Universiteit Gent & 7 & 147 & 6 & 21,00 \\
\hline 21 & Rutgers, The State University of New Jersey & 7 & 85 & 5 & 12,14 \\
\hline 22 & University of California, Los Angeles & 6 & 471 & 5 & 78,50 \\
\hline 23 & Louisiana State University & 6 & 288 & 6 & 48,00 \\
\hline 24 & University Michigan Ann Arbor & 6 & 283 & 6 & 47,17 \\
\hline 25 & $\mathrm{UCL}$ & 6 & 220 & 4 & 36,67 \\
\hline 26 & University of Pennsylvania & 6 & 213 & 6 & 35,50 \\
\hline 27 & Columbia University in the City of NY & 6 & 187 & 6 & 31,17 \\
\hline 28 & University of Arizona & 6 & 155 & 6 & 25,83 \\
\hline 29 & University of Calgary & 6 & 143 & 4 & 23,83 \\
\hline 30 & George Mason University & 6 & 142 & 5 & 23,67 \\
\hline
\end{tabular}


Table A8. Period 2010-2016.

\begin{tabular}{|c|c|c|c|c|c|}
\hline \multicolumn{6}{|c|}{ 2010-2016 } \\
\hline $\mathrm{R}$ & Institution & TS & $\mathrm{TC}$ & $\mathrm{H}$ & $\mathrm{TC} / \mathrm{TS}$ \\
\hline 1 & Orta Dogu Teknik Universitesi & 7 & 33 & 3 & 4,71 \\
\hline 2 & Erasmus University Rotterdam & 6 & 43 & 1 & 7,17 \\
\hline 3 & National Taiwan University of Science and Technology & 6 & 21 & 3 & 3,50 \\
\hline 4 & University of Oklahoma & 5 & 18 & 3 & 3,60 \\
\hline 5 & Universitat Koblenz-Landau & 5 & 16 & 1 & 3,20 \\
\hline 6 & Ben-Gurion University of the Negev & 5 & 4 & 1 & 0,80 \\
\hline 7 & City University of Hong Kong & 5 & 0 & 0 & 0,00 \\
\hline 8 & Tel Aviv University & 4 & 38 & 3 & 9,50 \\
\hline 9 & Bar-llan University School of Social Work & 4 & 21 & 3 & 5,25 \\
\hline 10 & KU Leuven & 4 & 15 & 2 & 3,75 \\
\hline 11 & University of Arizona & 4 & 13 & 1 & 3,25 \\
\hline 12 & Brock University & 4 & 12 & 1 & 3,00 \\
\hline 13 & Georgia State University & 4 & 12 & 1 & 3,00 \\
\hline 14 & Universidad de Granada & 4 & 9 & 2 & 2,25 \\
\hline 15 & University of Connecticut & 4 & 4 & 1 & 1,00 \\
\hline 16 & University of Calgary & 4 & 3 & 1 & 0,75 \\
\hline 17 & College of Charleston & 4 & 2 & 1 & 0,50 \\
\hline 18 & University of West Florida & 4 & 2 & 1 & 0,50 \\
\hline 19 & Brunel University London & 3 & 65 & 3 & 21,67 \\
\hline 20 & University of Haifa & 3 & 21 & 3 & 7,00 \\
\hline 21 & Universitat Heidelberg & 3 & 15 & 2 & 5,00 \\
\hline 22 & lowa State University & 3 & 13 & 2 & 4,33 \\
\hline 23 & Christian-Albrechts-Universitat zu Kiel & 3 & 11 & 1 & 3,67 \\
\hline 24 & Kansas State University & 3 & 2 & 1 & 0,67 \\
\hline 25 & Brigham Young University & 3 & 1 & 1 & 0,33 \\
\hline 26 & Bowling Green State University & 3 & 1 & 1 & 0,33 \\
\hline 27 & University of Liverpool & 3 & 1 & 1 & 0,33 \\
\hline 28 & McGill University & 3 & 0 & 0 & 0,00 \\
\hline 29 & Kennesaw State University & 3 & 0 & 0 & 0,00 \\
\hline 30 & University of Macau & 3 & 0 & 0 & 0,00 \\
\hline
\end{tabular}

